\title{
LCA and nutritional assessment of southern Benin market vegetable gardening across the production continuum
}

\author{
Angel Avadí ${ }^{1,2,3} \cdot$ Nounagnon Richard Hodomihou $^{4,5} \cdot$ Guillaume Lucien Amadji ${ }^{4}$ Frédéric Feder ${ }^{1,2,5}$
}

Received: 13 January 2021 / Accepted: 8 September 2021 / Published online: 21 September 2021

(c) The Author(s) 2021

\begin{abstract}
Purpose The goal of this work is to analyse the environmental impacts across the productive continuum of market gardening in southern Benin, to determine whether significant differences exist amongst the types of production, and to highlight their hotpots suitable to improvement. Moreover, the relative nutritional quality of products from different production system types were compared to determine whether there were differences and to assess them in relation to the associated environmental impacts.

Methods LCA and laboratory analyses were performed on a representative sample of systems and products (carrot, cucumber, tomato, lettuce, watermelon). The resulting scores (single scores for LCA and Nutrient Rich Food scores for nutritional quality) were statistically treated to identify the representativeness of their differences across production sites and production types (featuring distinctive production strategies: Conventional — synthetic fertilisers and pesticides, Organic — organic fertilisers and pesticides and "Lean" - limited inputs).

Results and discussion Statistically significant differences across environmental scores were found amongst production sites (for carrot, lettuce and all crops) and types (for carrot and all crops). For tomato, produced on all sites, under all production types, the natural and management-driven variability is large enough that no significant differences were found. Impacts are dominated by direct emissions from (over-)fertilisation and by fuel consumption for water pumping. Despite the absence of significant differences amongst production system types regarding the contents of both $\beta$-carotene and polyphenols, the nutritional indices suggest at least marginal differences across types regarding the overall nutritional value of carrot and tomato across types. Based on the limited data available, it cannot be stated that such differences are statistically significant. For carrot, there seems to be a correlation between nutritional quality and environmental impacts, with higher nutritional scores associated with lower environmental impacts. For tomato, it does not seem to exist a correlation.

Conclusions Significant differences in environmental scores exist amongst the types of production, with the larger impact associated with organic production, whilst that no statistically significant differences on nutritional quality can be demonstrated across types. Overall improvement of these systems would be achieved by less energy-intensive irrigation, organic waste processing platforms to reduce volatilisation losses, knowledge on the fertilising value of organic waste, and agricultural extension services or technical guides on good agricultural practices to reduce over-fertilisation and other negative environmental impacts.
\end{abstract}

Keywords Environmental assessment · Organic and conventional agriculture $\cdot$ Organic fertiliser $\cdot$ Nutritional indices

Communicated by Sarah Jane McLaren

Angel Avadí

angel.avadi@cirad.fr

1 CIRAD, UPR Recyclage et risque, Montpellier 34398, France

2 Recyclage et risque, Univ Montpellier, CIRAD, Montpellier, France
3 Research Group for Environmental Life Cycle Sustainability Assessment, ELSA, Montpellier, France

4 Faculté des Sciences Agronomiques, Université d'Abomey-Calavi, Cotonou, Benin

5 CIRAD, UPR Recyclage et Risque, Laboratoire Mixte International IE SOL, Dakar 18524, Senegal 


\section{Introduction}

\subsection{Environmental assessment of organic vs. conventional agriculture in Africa}

In sub-Saharan Africa, urban and peri-urban (i.e. suburban) market gardening activities supply fresh vegetables to growing cities featuring consumers assigning increasing importance to these products (Chauvin et al. 2012; OCDE/ FAO 2016). These activities can be conducted throughout the year depending on the climatological conditions and the pressure of pests. Production is dominated by smallholder —often family-managed - farms, favouring as few intermediaries as possible (Ahouangninou 2013; Gollin 2014) (i.e. "short circuits"). Smallholder production limits losses, waste generation and intermediaries, but lacks the benefits of economies of scale (Sarris and Morrison 2010; Gollin 2014). These productions are essential for diversifying the diet, providing nutrients and thus remedying the deficiencies that are prevalent in these regions (Sarris and Morrison 2010; FAO 2019a). Nevertheless, these crops require high amounts of fertilisation and irrigation. The agronomic and climatic conditions (absence of plant cover, short crop cycle, pressure from pests, use of phytosanitary products, etc.) generate various environmental risks (Feder et al. 2015; Hodomihou et al. 2016). In southern Benin, amongst the intensified conventional market gardening areas, a so-called lean approach ("Agriculture raisonné" in French (Rosenberg and Gallot 2002)) has been developed to reduce both costs and the negative impact of chemical fertilisers and pesticides on the particularly sensitive ecosystem (sandy coastal soils, shallow groundwater). Moreover, a small number of organic production systems exist, which avoid the use of synthetic phytosanitary and fertilising substances. The benefits and environmental sustainability of the latter two production system types (from now on referred to as 'types') are poorly quantified, compared to those of the conventional production.

Globally, several examples of LCA use to compare the environmental impacts of organic and conventional systems exist (e.g. de Boer 2003; Knudsen et al. 2014; Meier et al. 2015; Boone et al. 2019), yet only a few assess the statistical significance of differences amongst systems (e.g. Tuomisto et al. 2012). Literature reviews and statistical analyses have been performed to explore the nutritional differences amongst products from organic and conventional systems (e.g. Worthington 2001; Popa et al. 2019). No comparative environmental assessment or organic and conventional production has been published to date on African vegetable systems, yet a recent publication explored the scope of research on West African organic food production, and highlighted the need for further research in order to develop the sector and its potential positive impacts (El Bilali 2020).

There is moreover a global perception that organic agricultural products have lower embedded environmental impacts than conventional ones, or that may be healthier and safer (Magkos et al. 2006; Suciu et al. 2019; El Bilali 2020). Moreover, the integration of nutritional concerns in LCA and in environmental assessment in general has been identified as an urgent need (Weidema and Stylianou 2019; Green et al. 2020).

The goal of this work is to analyse the environmental impacts across the productive continuum (i.e. the range of agricultural practices) of market gardening in southern Benin (West Africa), to determine whether statistically significant differences exist amongst production types and to highlight their associated hotspots suitable for improvement. The nutritional positive and negative implications of the different production types are also explored, to confirm or challenge literature on the subject suggesting that there is no solid evidence that organic and conventional products differ in terms of concentrations of various nutrients (Bourn and Prescott 2002; Mie et al. 2017; Popa et al. 2019).

\subsection{Market gardening in southern Benin}

There are four main production communes/perimeters (from now on referred to as 'sites') devoted to market gardening in southern Benin (Fig. 1): Grand-Popo, Ouidah, Cotonou and Sèmè-Kpodji. Amongst the leading vegetable species produced (from now on referred to as 'crops'), the following were studied: carrots, tomatoes, leafy vegetables such as lettuce and Cucurbitaceae (cucumber and watermelon). A more detailed mapping of surveyed combinations of a site, a type and a crop (from now on referred to as 'systems') is available in the Supplementary Material.

Beninese market gardening is an eminently manual activity (i.e. not mechanised), the vast majority of which is carried out by human labour. One exception that is beginning to become widespread is irrigation. Although the majority of producers use manual irrigation, simple sprinkler irrigation systems are increasingly being used by the most successful producers (as this requires significant investment in pipes, pumps, etc.). A priori, three distinguishable production types exist, according with their inputs strategy.

Conventional vegetable systems dominate the production continuum, and are based on the use of organic and/or mineral fertilisers and synthetic chemical pesticides (Akogbeto and Noukpo 2005; Ahouangninou et al. 2011). To optimise crop yields in most of these systems located on sandy soils in the southern Benin coastal sedimentary basin, organic and/or mineral over-fertilisation and inappropriate or excessive use of pesticides are often observed. These uncontrolled 


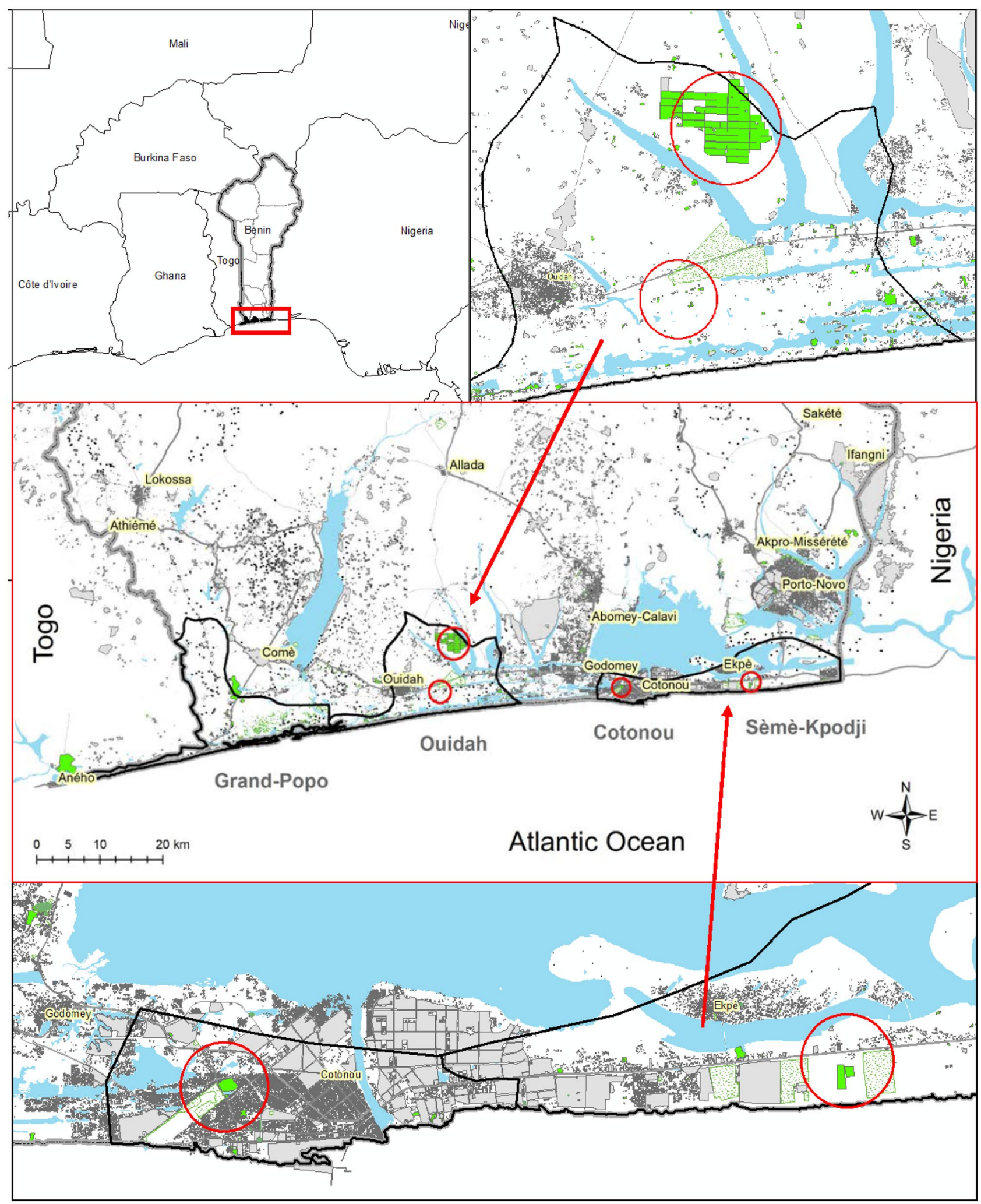

Fig. 1 Geographical location of southern Benin vegetable gardening (studied production sites are highlighted) 
farming practices generate risks of contamination of soil, vegetables, groundwater and surface water by nitrates, pesticide residues and trace elements (Agbossou et al. 2003; Atidegla and Euloge 2010; Yehouenou et al. 2010; Atidegla et al. 2011; Ahouangninou et al. 2013; Perrin et al. 2015).

Lean market gardening systems aim at reconciling the optimisation of productivity with environmental preservation, by controlling the quantities of inputs, in particular chemical fertilisers and phytosanitary products (Ahouangninou 2013). In theory, market gardeners only apply phytosanitary treatments when necessary, at the right time and with the right dose and equipment.

Organic vegetable production systems use natural inputs, such as organic fertilisers and biopesticides, whilst excluding the use of chemical fertilisers and pesticides (Ahouangninou 2013). They are based on production methods that are close to natural biological cycles, whilst practicing a rational management of technical routes: recycling of organic materials (compost and animal waste such as poultry droppings and cattle dung), crop rotation/associations and biological control. These systems are practiced by few producers in southern Benin, due to the many constraints encountered during production: difficulties in accessing organic seeds, difficulties related to organic fertiliser sources and quality, pest management methods that are sometimes restrictive for the farmer, low yields under certain conditions, limitations in market access and the often too long and expensive certification process. Often, farmers start testing organic systems in parcels devoted to self (i.e. household) consumption, featuring limited inputs and yields. Most of the market gardeners who have adopted the organic system belong to the Association pour le Maintien de l'Agriculture Paysanne (AMAP-Bénin) network. This association brings together organic vegetable producers certified by the Participative Guarantee System (GSP), consumers and processors. GSPs are quality assurance systems, awarded locally by the Federation of Producers' Unions of Benin (FUPRO-BENIN) to certify producers on the basis of active participation of the stakeholders concerned, and are built on a basis of trust, networks and knowledge exchange. Thus, consumers and producers agree on the agronomic methods to be used in compliance with the charter of peasant agriculture and the organic market gardening specifications.

\section{Material and methods}

\subsection{Goal and scope}

This study focused on the sites highlighted in Fig. 1. The environmental and nutritional features of vegetables produced in these sites were determined by means of analyses, LCA and nutritional indices.

The boundaries of the LCA study included the provision (cradle to consumption unit gate) of agricultural inputs, the crop of interest and its related emissions (Fig. 2). The production (cradle to production unit gate) of inputs was not explicitly modelled, but retrieved from databases. The distribution of vegetable products was excluded, as the study features a cradle-to-farm gate scope.

To construct the life cycle inventories, primary data were collected by means of surveys administered to producers

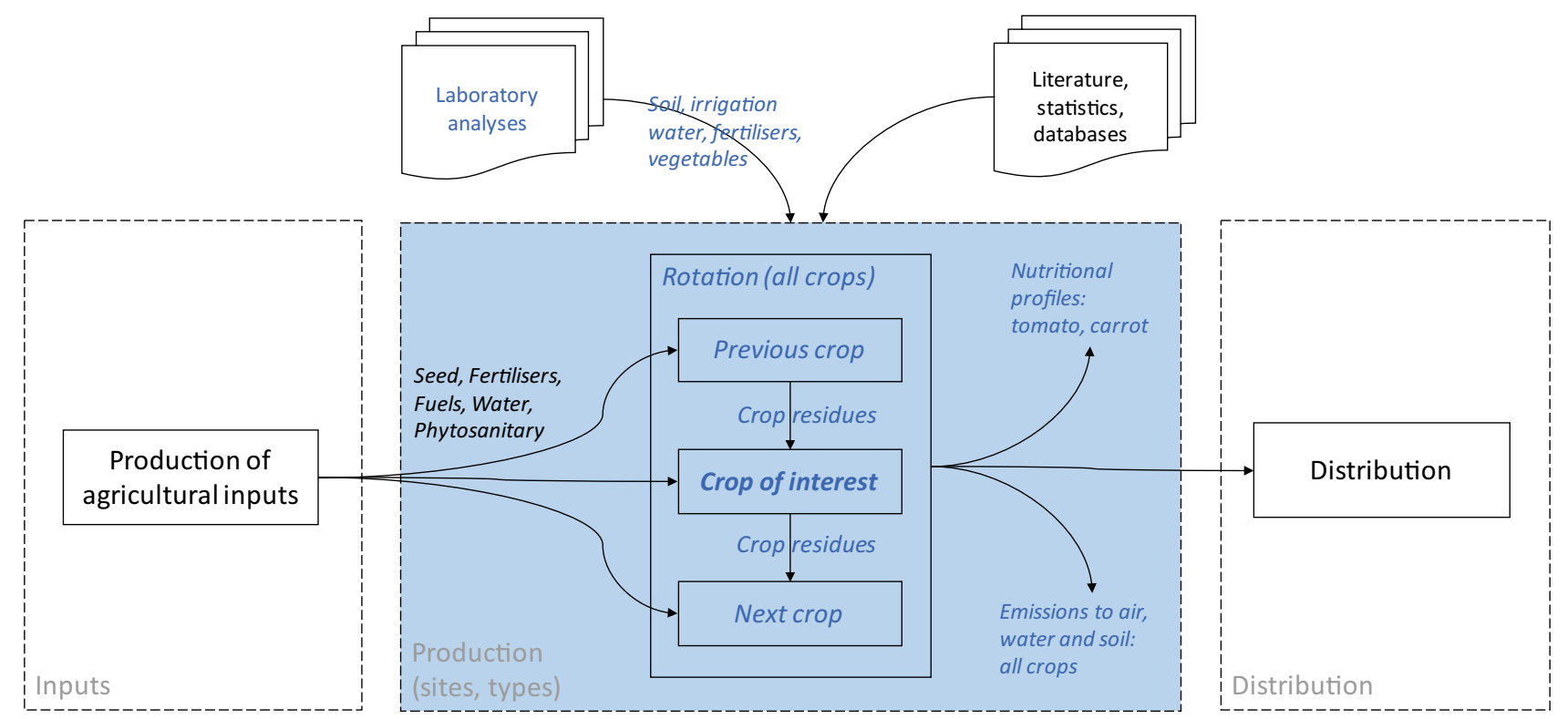

Fig. 2 System boundaries of the southern Benin market vegetable gardening LCA (text in blue represents primary data and the light blue background represents the modelled elements) 
in three of the four main market vegetable gardening communes of southern Benin (production sites). At each site, a sample of farms was surveyed, at the level of the production unit, where each production unit corresponds to a crop of interest associated with a specific producer, a production type and a site. Production types were define $d$ a priori as Conventional, Lean and Organic (see Sect. 3.1), yet the study focused on the productive continuum, as one of the objectives was to confirm or disprove this a priori classification. Production sites were also identified a priori, based on their urban and peri-urban settings: Houéyiho, Ouidah and Sèmè-Kpodji (see details in the Supplementary Material). The data obtained represent the production of the year 2018, in the non-rainy season (e.g. outside the drainage period).

Inventories and impacts were computed per production unit, and then aggregated per crop, per production type and per production site. Means of impacts were computed for each aggregation of production units.

In agricultural systems, especially when comparing different production types (e.g. organic vs. conventional), it is advisable to use multiple (and contrasting) functional units, which express the impacts of production in mass and area units (Meier et al. 2015; Salou et al. 2016). Therefore, we selected $1 \mathrm{t}$ of product and 1 ha of production as functional units.

\subsection{Life cycle inventories}

All relevant agricultural inputs and emissions were taken into account, but agricultural infrastructure and equipment were excluded, as their impacts in non-mechanised agricultural activity are negligible.

The effects and impacts of fertilisers should be reasoned at the crop rotation scale (Nemecek et al. 2001; Brankatschk and Finkbeiner 2015; Liao et al. 2015; Koch and Salou 2016), especially in a context of short cycles (the tropical vegetable cycle lasts between 1 and 4 months), and when contrasting different types of agricultural production systems (Meier et al. 2015). Considering a rotation instead of a single, isolated crop allows to allocate the delayed effects of each crop's inputs and outputs, as well as that of special crops (e.g. catch crops), to the whole rotation (Koch and Salou 2016; Costa et al. 2020). Therefore, inventories were constructed for each production unit, but taking into account previous and subsequent crops in the rotation for the estimation of direct field emissions (Fig. 2), for which the AGRIBALYSE v1.3 (Koch and Salou 2016) methodology was used, except for nitrogen emissions, for which the Indigo-N v2.7 (Bockstaller and Girardin 2010) method, more suitable for tropical environments (after adaptations on the rainy periods), was retained. Indigo- $\mathrm{N}$ allows modelling $\mathrm{N}$ emissions from crop rotations, in this case depicted as the succession of the previous, current (i.e. the crop of interest) and next crops. The estimation of direct emissions was informed by laboratory analyses on samples of soil, irrigation water and organic fertilisers.

Background data was taken from AGRIBALYSE v1.3 and ecoinvent v3.4, which follow a very similar structure and rules; thus, data harmonisation was not necessary. Suitable proxies were used when specific background processes were not available. For instance, transport of agricultural inputs was modelled as EURO3 transport by 3.5-7.5 t lorries (despite the bulk of African transportation systems being either not standardised or pollution standards not enforced), the provision of all seeds was modelled as the ecoinvent process carrot seed (with mass adjusted according to each crop's seed weight) and various phytosanitary molecules such as acetamiprid, abamectin and emamectin benzoate were modelled as ecoinvent generic inorganic chemicals.

As we focused on individual crops, and disregarded associated crops, no allocation of impacts between co-products was necessary, except for the allocation of fertilisers and their impacts (i.e. direct emissions) amongst crops in a rotation. This allocation is based on biophysical criteria, and was made by calculating direct nitrogen emissions with Indigo-N.

\subsection{Life cycle impact assessment}

The impact assessment was based on the ILCD 2011 Midpoint + v1.0.9 method, May 2016 (EC-JRC 2012), broadly aligned with the recent recommendations of the European Commission on the environmental footprint of products (Product Environmental Footprint (PEF)) (EC 2018). ILCD 2011 includes a single score, expressed in the dimensionless unit "points" $(\mathrm{Pt})$, but no aggregation into protection areas, so the weighting is set at 1 per impact category. We express the impact assessment results in terms of the single score (endpoints) and four selected impact categories (midpoints): climate change, eutrophication, acidification and freshwater ecotoxicity. These impact categories were selected based on their known relevance in agricultural LCA (Haas et al. 2000; Dijkman et al. 2017). The comparisons across sites, types and crops is mainly done by means of their single scores, as more detailed comparisons based on individual impact categories are more complex in the sense that many more data points need to be contrasted, either numerically of graphically. Single scores, which provide a simplified picture of the estimated environmental impacts, are useful in such situations where a more generic $\mathrm{A}>\mathrm{B}$ type of comparison is expected (Kalbar et al. 2017). Nonetheless, as recommended by the relevant ISO standard (ISO 2006), all impacts disaggregated per impact category (midpoints) are available in the Supplementary Material. 
ILCD integrates USEtox (Rosenbaum et al. 2008; Fantke (Ed.) et al. 2017), the consensus toxicity model, to calculate all toxicity impact categories. An adjustment was made to the model: the characterisation factor for climate change of " $\mathrm{CO}_{2}$ in air" was changed from -1 to 0 , because we considered that the $\mathrm{CO}_{2}$ in air absorbed by plants and reemitted in the short term, as is the case for annual crops, does not represent carbon sequestration.

SimaPro v8.5.5.5.2 was used to calculate the impacts. In order to find eventual significant differences across mean impacts amongst crops, sites, and especially production types, the results were statistically processed with the $\mathrm{R}$ v3.5 software. Multiple Tukey's pairwise comparisons were made, by crop and crop variety, by site and by production type.

Selected midpoint values were compared with reported values for other global vegetable systems, as very few LCA studies have focused on African vegetable production.

\subsection{Nutritional comparison}

The relative nutritional value of vegetables produced across sites and production types was computed by means of a nutritional index inspired by the Nutrient Rich Food index (Drewnowski and Fulgoni 2008). The computation of these indices was informed by laboratory analyses on vegetable samples. The index subtracts the nutrients to limit in food from their content of desired nutrients. Both sets of features are computed as the arithmetic mean of each considered nutrient divided by a reference value ( $100 \mathrm{~g}$ ) and, in the case of $\mathrm{NRF}_{\mathrm{n}}$, scaled by the foodstuff's energy density in $\mathrm{kcal} / \mathrm{g}$ (Darmon et al. 2005, 2009). Computations are defined by Eq. 1 to Eq. 3 (Drewnowski and Fulgoni 2008; Drewnowski et al. 2009):

Nutrient Rich Food $\left(\mathrm{NRF}_{n}\right)=\frac{\sum_{1}^{n}\left(\frac{\text { Nutrient }}{\text { Daily values }} * 100\right) / n}{\text { Energy density }}$

Limited nutrients score $\left(\operatorname{LIM}_{m}\right)=\frac{\sum_{1}^{m}\left(\frac{\text { Daily amount }}{\text { Maximum recommended values }} * 100\right) / m}{100 \mathrm{~g}}$

Nutrient Rich Food (NRFn.m) $=\mathrm{NRF}_{n}-\mathrm{LIM}_{m}$

where Nutrient refers to the amount of a nutrient in the foodstuff, Daily values are recommended daily intakes for each nutrient, and Energy density is the foodstuff's energy content in kcal; Daily amount represents the intake of a nutrient to limit per $100 \mathrm{~g}$ of foodstuff, and Maximum recommended values are recommendations of maximum daily intakes per nutrient to limit.

In this case, desired nutrients include trace elements $(\mathrm{Ca}$, $\mathrm{Fe}, \mathrm{Mn}, \mathrm{Zn}$ ), vitamins (A and B-12), antioxidants - e.g. polyphenols, despite their role in human health being somewhat disputed and no intake recommendations existing to date (Martin 2009; Pérez-Jiménez et al. 2010; Joubert and Gelderblom 2016; Cory et al. 2018; Del Bo et al. 2019; Koch 2019; Truzzi et al. 2020) — and dietary fibre. Nutrients to limit include toxic trace elements $(\mathrm{Pb}, \mathrm{Cd}, \mathrm{As})$ beyond intake limits recommendations (as vegetables lack the classic triad of nutrients to limit: added sugar, sodium and saturated fatty acids (Darmon et al. 2009)), and "excess" polyphenols content beyond a quasi-reference value of $500 \mathrm{mg} /$ day associated with a healthy diet that includes five portions of fruits and vegetables per day (Williamson and Holst 2008; Martin 2009). There is no clear consensus on the potential negative effects of excess polyphenol intake (Duthie et al. 2003); thus, we chose to, under a precautionary principle, consider it as a nutrient to limit. To contrast such a risky choice, we computed a version of $\mathrm{NRF}_{n, m}$ which does not consider polyphenol contents beyond $500 \mathrm{mg} /$ day as a nutrient to limit.

There is literature on the risks of excessive vitamin intake, but mainly related with nutritional supplements (e.g. Wooltorton 2003) or fortified foodstuff (e.g. Lietz 2020), not with fresh vegetable produce.

Nutritional differences amongst products were analysed with 1-way and 2-way ANOVA tests to determine the significance at the $p=0.001$ level.

\subsection{Laboratory analyses}

Soil samples, taken for each production unit, were analysed in the Soil Science Laboratory of the Faculty of Agronomic Sciences at the University of Abomey-Calavi (FSA-UAC), in Benin, to determine $\mathrm{pH}$, total $\mathrm{C}$ and $\mathrm{N}$ content, organic matter and mineral $\mathrm{N}$ content, particle size analysis (clay, silt and sand), electrical conductivity and soil available water capacity that were also measured. Additional analyses were conducted at the Analytical Means Laboratory (LAMA) of the IRD (Development Research Institute) in Dakar, for trace element contents in soil.

The organic amendment and fertiliser samples, taken for each site, were analysed in the LAMA, to determine their total $\mathrm{N}$, mineral N, P, K and trace element contents.

Samples of irrigation water, taken for each site, were analysed to determine the contents of nitrates and phosphates (Laboratory of Soil, Water and Environmental Sciences of the National Agricultural Research Institute of Benin-LSSEE/INRAB), and certain pesticides such as lambda-cyhalothrin (Central Food Safety Control Laboratory-LCCSSA).

Vegetable (plant) samples, taken for each production unit, were analysed in the FSA-UAC to determine their levels of $\mathrm{Ca}, \mathrm{Fe}, \mathrm{Mn}$ and $\mathrm{Zn}$, as well as residues of the pesticide lambda-cyhalothrin. Further analyses were conducted in France (SGS France) to determine vegetable samples' 
contents of $\beta$-carotene (as a precursor to vitamin $\mathrm{A}$; test: Visible HPLC), vitamin B12 (test: ME340 HPLC) and polyphenols (as gallic acid, test: Folin-Ciocalteu).

\section{Results and discussion}

\subsection{The market vegetable gardening production continuum of southern Benin}

\subsubsection{Characteristics of studied sites}

From a climatic point of view, the market gardening areas of southern Benin are under the influence of the sub-equatorial climate, of the Guinean type, characterised by four more or less marked seasons of unequal duration (Boko 1988), namely: a long dry season from mid-November to midMarch, a great rainy season from mid-March to mid-July, a small dry season from mid-July to mid-September and a short rainy season from mid-September to mid-November.

Rainfall is relatively high, averaging $1200 \mathrm{~mm}$ per year. The rainfall regime is bimodal, with peaks observed in the months of June and October, respectively, for both rainy seasons. The average temperature is $27^{\circ} \mathrm{C}$, varying from 24 to $30^{\circ} \mathrm{C}$ in the rainy season and from 23 to $33^{\circ} \mathrm{C}$ in the dry season. The differences between the hottest and the coldest month do not exceed $4{ }^{\circ} \mathrm{C}$. The monthly relative humidity varies between 75 and $90 \%$.

From a geological and pedological point of view, the market gardening perimeters of southern Benin are located on the coastal sedimentary basin which is situated on the edge of the Atlantic Ocean and groups together two topographical subunits: the coastal plain and the "terre de barre" — ferrallitic, slightly desaturated clayey-sandy soils (Azontondé 1993) plateaux south of the Lama depression. The dominant soils for market gardening are found in the coastal plain and are sandy soils called raw mineral soils, consisting of fine sands, low in organic matter, highly permeable and well drained.

The dominant soils in southern Benin are sandy, moderately acid and feature low contents of organic matter (Table 1).

From a hydrogeological point of view, the water table is shallow (less than $1 \mathrm{~m}$ in places in Cotonou, and between 1 and $6 \mathrm{~m}$ in southern Benin), and is therefore highly influenced by rainwater and leachate, leading to contamination of groundwater by pollutants of all kinds (Atidegla and Euloge 2010). The very low altitude areas correspond to swamps, which are the convergence axes of surface water, hypodermic (subsurface) flows and groundwater.

Phosphate and nitrate contents of the (borehole) irrigation water collected in the Houéyiho perimeter $(46 \pm 11$ and $126 \pm 25.7 \mathrm{mg} / \mathrm{L}$, respectively) are significantly higher $(p$-value $<0.05)$ than those of Sèmè-Kpodji $(3.5 \pm 1.8$ and
Table 1 Results of southern Benin soil analyses

\begin{tabular}{|c|c|c|c|c|}
\hline Parameter & Unit & Sèmè-Kpodji & Houéyiho & Ouidah \\
\hline pH water & Unitless & 6.53 & 7.40 & 5.95 \\
\hline $\mathrm{pH} \mathrm{KCl}$ & Unitless & 6.10 & 7.10 & 5.42 \\
\hline C organic & $\mathrm{g} / 100 \mathrm{~g}$ & 1.05 & 1.30 & 0.93 \\
\hline $\mathrm{N}$ total & $\mathrm{g} / 100 \mathrm{~g}$ & 0.07 & 0.12 & 0.09 \\
\hline $\mathrm{C} / \mathrm{N}$ & Unitless & 15.54 & 11.55 & 10.23 \\
\hline Organic matter & $\mathrm{g} / 100 \mathrm{~g}$ & 1.82 & 2.24 & 1.60 \\
\hline $\mathrm{N}-\mathrm{NH}_{4}^{+}$ & ppm & 3.64 & 3.87 & 3.67 \\
\hline $\mathrm{N}-\mathrm{NO}_{3}^{-}$ & ppm & 4.77 & 8.69 & 6.44 \\
\hline $\begin{array}{l}\mathrm{N} \text { mineral (ammonium } \\
\text { + nitrates) }\end{array}$ & ppm & 8.41 & 12.55 & 10.12 \\
\hline Conductivity & $\mu \mathrm{S} / \mathrm{cm}$ & 0.34 & 0.16 & 0.21 \\
\hline Clay & $\%$ & 4.88 & 6.42 & 8.02 \\
\hline Silt & $\%$ & 3.82 & 3.83 & 3.75 \\
\hline Sand & $\%$ & 90.81 & 89.37 & 87.73 \\
\hline Texture & & Sandy & Sandy & Sandy \\
\hline
\end{tabular}

Available water capacity $(\mathrm{mm} / \mathrm{cm})$ across sites: $1.12 \pm 0.15$

$59.3 \pm 17.3 \mathrm{mg} / \mathrm{L}$, respectively) and Ouidah $(3.8 \pm 0.9$ and $31.3 \pm 10.3 \mathrm{mg} / \mathrm{L}$, respectively). The standard deviations correspond to differences amongst measured values per site. By comparing the average nitrate contents of the borehole waters of these market gardening perimeters with the maximum allowed in drinking water, which is $50 \mathrm{mg} / \mathrm{L}$ (WHO 2011), it can be seen that the nitrate contents of the waters of Houéyiho and Sèmè-Kpodji are higher than this standard. Assogba-Komlan et al. (2007) reported that over-fertilisation in the market gardening perimeters of the coastal basin of southern Benin increases the risks of groundwater pollution by nitrates due to the sandy texture of the soils which are highly filtering. The phosphate and nitrate contents measured in this study are much higher than those obtained in 2011 by Ahouangninou (2013), thus indicating an increase in nitrate and phosphate pollution over time.

As for the analyses of lambda-cyhalothrin pesticide residues in these waters, the results obtained in all the perimeters are always below the detection limit, indicating no trace of contamination in pesticide in these irrigation waters. These results confirm those obtained by Ahouangninou (2013), who reported that the irrigation water in these areas does not contain pesticide residues. Irrigation waters were not analysed for trace elements, but it is expected that their content of such contaminants would be rather high (Koumolou et al. 2013; Djouaka et al. 2016).

\subsubsection{Fertilisation}

Numerous studies on fertilisation practices in market gardening in southern Benin have shown that high doses of organic and mineral fertilisers are applied to market 
gardening soils (Assogba-Komlan et al. 2007; Atidegla et al. 2011; Perrin et al. 2014). Doses of organic matter such as poultry droppings and cottonseed residues above $40 \mathrm{t} / \mathrm{ha} /$ cycle, and mineral fertilisers such as urea and NPK above $600 \mathrm{~kg} / \mathrm{ha} /$ cycle, have been reported as common occurrence for vegetables such as Solanum macrocarpum (Assogba-Komlan et al. 2007). These high application rates of organic and mineral fertilisers have little influence on vegetable yields on sandy soils in the southern Benin coastal sedimentary basin, but generate clear environmental risks (Assogba-Komlan et al. 2007; Perrin 2013; Perrin et al. 2014). A recent article (Atidegla et al. 2018) states that all producers over-fertilise, as they exceed the recommended $400-\mathrm{kg} / \mathrm{ha}$ mineral fertiliser rate by up to $300 \%$. In addition, the article claims that only $21 \%$ of market gardeners comply with the recommended rate of $20 \mathrm{t} / \mathrm{ha}$ of poultry droppings. It has been noted that over-fertilisation is a global issue that greatly worsens the environmental impacts of both conventional and organic agricultural systems (Foteinis et al. 2021).

According with our surveys, the most common organic fertiliser used in southern Benin is poultry droppings. These have variable characteristics (e.g. $\mathrm{N}$ and $\mathrm{C}$ content) and its trace element content is considerably higher than that of poultry droppings used in France (Supplementary Material). We determined via analyses a mean $\mathrm{N}$ content of $1.89 \% \mathrm{DM}$, with a $9.5 \%$ humidity content.

Over-fertilisation of market vegetables was noted via our surveys, notably in Conventional systems, but not in the orders of magnitude reported in the literature. We found mean inputs $8.0 \mathrm{t}$ organic fertilisers/ha and $170 \mathrm{~kg}$ mineral $\mathrm{N}$ fertilisers/ha in Conventional systems (for a total input of $\sim 300 \mathrm{~kg} \mathrm{~N} / \mathrm{ha}$ ), $2.5 \mathrm{t} / \mathrm{ha}$ organic and $64 \mathrm{~kg} / \mathrm{ha}$ mineral in Lean systems ( $104 \mathrm{~kg} \mathrm{~N} / \mathrm{ha})$ and $14.0 \mathrm{t} / \mathrm{ha}$ organic and $0 \mathrm{~kg} / \mathrm{ha}$ mineral in Organic systems ( $225 \mathrm{~kg} \mathrm{~N} / \mathrm{ha})$. The $\mathrm{N}$ demands of vegetables are in the order of $170-400 \mathrm{~kg} \mathrm{~N} /$ ha for tomato, 120-170 for carrot, 50-80 for lettuce and 160 for Cucurbitaceae (Neuweiler and Krauss 2017). See Sect. 3.3 for fertiliser and other inputs per crop, site and production type.

\subsubsection{Phytosanitary control}

Our surveys explored the use of phytosanitary substances. To manage pests on vegetable crops in southern Benin, producers generally use chemical pesticides in Conventional systems, and chemical (e.g. Laser 480SC) or local (e.g. plant-based) biopesticides in Lean or Organic systems.

In Conventional market gardening, more than 24 commercial chemical pesticide preparations are used by growers (Akogbeto and Noukpo 2005; Ahouangninou et al. 2011, 2013; Agnandji et al. 2018), to combat a variety of pests (Table 2). The majority of these identified pesticides are emulsifiable concentrates belonging to the families of organophosphates, pyrethroids, carbamates and benzimidazoles. The fungicides identified are wettable powder formulations. Nematicides such as carbofuran have also been identified. Several authors have reported that most of these insecticide formulations used by vegetable growers are not suitable for the protection of vegetable crops, but are recommended and registered for cotton pest control (Agbossou et al. 2003; Assogba-Komlan et al. 2007; Azandeme-Hounmalon et al. 2014). For instance, Azandeme-Hounmalon et al. (2014) found that $65 \%$ of market gardeners use cotton insecticides containing lambda-cyhalothrin and profenofos, at doses that vary from one market garden to another. Some farmers use it

Table 2 Crops grown by market gardeners, their main threatening pest and the main pesticide used

\begin{tabular}{|c|c|c|c|}
\hline Crop & Scientific name & Main pest & Main commercial pesticide \\
\hline Amaranth & Amaranthus cruentus $\mathrm{L}$ & Heliothis recurvalis $\mathrm{L}$ & Acarius $18 \mathrm{EC}$ \\
\hline Aubergine & Solanum melongena $\mathrm{L}$ & Bemisia tabaci $\mathrm{G}$ & Cypercal P 330 EC \\
\hline Lettuce & Lactuca sativa $\mathrm{L}$ & Bremia lactucae $\mathrm{R}$ & Emacot Fort \\
\hline Cabbage & Brassica oleracea var. capitata $\mathrm{L}$ & Mycosphaerella brassicicola $\mathrm{S}$ & Laser $480 \mathrm{SC}$ \\
\hline Tomato & Lycopersicon esculentum Mil & Phytophthora sp. M & Pacha 25 EC \\
\hline Beet & Beta vulgaris $\mathrm{L}$ & Pegomyia betae $\mathrm{C}$ & Dursban B-200/18 EC \\
\hline Vernonia & Vernonia amygdalina $\mathrm{D}$ & Sphaerocoris annulus $\mathrm{F}$ & Lambdacal P 630 \\
\hline $\begin{array}{l}\text { African eggplant (Grande } \\
\text { morelle) }\end{array}$ & Solanum macrocarpum $\mathrm{L}$ & Spodoptera frugiperda $\mathrm{S}$ & Tihan 1760-TEQ \\
\hline Great basil & Ocimum basilicum $\mathrm{L}$ & Aphis gossypii $\mathrm{G}$ & Coga $80 \mathrm{WP}$ \\
\hline Carrot & Daucus carota $\mathrm{L}$ & Psila rosae $\mathrm{F}$ & Lambdacal P 630 \\
\hline Cucumber & Cucumis savitus $\mathrm{L}$ & Acalymma vittatum $\mathrm{F}$ & Tihan 1760-TEQ \\
\hline Pepper & Capsicum sp. & Lygus lineolaris $\mathrm{P}$ & Dursban B-200/18 EC \\
\hline Turnip & Brassica rapa $\mathrm{L}$ & Pieris napi $\mathrm{L}$ & Pacha 25 EC \\
\hline
\end{tabular}

Source: Agnandji et al. (2018) 
in high doses with the intention of improving the effectiveness of crop protection, whilst other market gardeners mix several formulations such as lambda-cyhalothrin, profenofos and deltamethrin, without respecting the recommended doses, as noted via our surveys. Similarly, the frequency of crop treatments varies greatly amongst market gardeners. The primary objective of market gardeners is to increase productivity and financial profitability, in general at the expense of the environment and human health. This profitability drive does not take into account ecological costs and all the negative externalities of chemical input use.

In Lean or Organic market gardening, producers use alternative control methods that present fewer risks. These include the use of plant extracts such as Neem (Azadirachta indica), Hyptis suaveolens and Carica papaya, which are locally manufactured (Coulibaly et al. 2008; CORAF 2010), as noted via our surveys. The objective of introducing these biopesticides into vegetable production systems is to control crop pests whilst respecting ecological principles, human health and the environment. The use of biopesticides in crop pest control is considered an integral part of a sustainable production system, but their use remains very limited (Adékambi et al. 2010). Although biopesticides are less dangerous to agroecosystems and reduce the risk of residues in the food produced, some products have a slower onset of action or require a specific environment to be effective and could also have an impact on non-target organisms used in biocontrol (Birch et al. 2011).

Analysis results suggest levels below the detection limit of $10 \mu \mathrm{g} / \mathrm{kg}$ for pesticide residues in all vegetable samples.

\subsubsection{Other practices}

Our surveys made it possible to identify strategies for controlling pests through the implementation of crop rotations and associations. Specific crop rotation practices are also deployed as good pest control strategies on Lean/Organic vegetable systems. These practices generally involve alternating between crop cycles, crops attacked by different groups of pests or crops that use different layers of the soil. For example, lettuce-amaranth-carrot, tomato-amaranthleaf-vernonia, spiny turnip-amaranth-carrot and great nightshade-amaranth-leaf rotations are observed. Crops such as turnips, radishes and amaranth often precede nematode sensitive crops such as tomatoes, lettuce and Cucurbitaceae (cucumber, zucchini, melon, watermelon). Vernonia (Vernonia amygdalina) is a plant with little parasite and low-nutrient requirements, so it is often placed at the end of rotation to interrupt the cycle of certain pests.

In addition to climatic conditions, the factor favouring the practice of market gardening in the coastal sedimentary basin of southern Benin is the easy accessibility to groundwater of acceptable quality and unsalted, due to the shallow depth of the water table, which facilitates the construction of traditional wells or boreholes. The irrigation methods used are traditional, as note via our surveys in line with a previous report by Atidegla et al. (2011), using with watering cans (5\%) and improved systems (95\%) based on the use of internal combustion or electric pumps for water extraction and pipes for the distribution of pressurised water to plants through sprinklers.

As confirmed by our surveys, market gardening products are manually harvested. Harvesting and product distribution or sale strategies vary according to the crop.

\subsection{Nutritional comparison}

Mean content of trace nutrients and contaminants (trace elements) in tomato and carrot are often different from each other but are not ordered identically according to the three agronomic modalities (Table 3). Contents of vitamin B12 were consistently $<0.3 \mu \mathrm{g} / 100 \mathrm{~g}$. For carrots, the contents of $\beta$-carotene and polyphenols are higher for lean management; the organic modality always has the lowest contents. This order is reversed for zinc contents. For $\beta$-carotene and polyphenols, Ryan-Joiner normality tests were conducted, with positive results. A 2-way ANOVA allowed to conclude that, for polyphenols, there were significant differences ( $p$-value $<0.002)$ amongst carrots and tomatoes, whilst no significant differences ( $p$-value $>0.05$ ) existed for $\beta$-carotene. For both crops, 1-way ANOVAs revealed no significant differences $(p$-value $>0.1)$ amongst production types for both $\beta$-carotene and polyphenols.

Analyses conducted to determine trace element levels in vegetable samples were not comprehensive, as the focus of vegetable analyses was on desirable nutrients. Therefore, analyses were conducted to measure $\mathrm{Ca}, \mathrm{Fe}, \mathrm{Mn}$ and $\mathrm{Zn}$ (micronutrients) for all vegetables, but $\mathrm{Pb}, \mathrm{Cd}$ and $\mathrm{As}$ (contaminants) were measured for tomato only. Based on the fact that no significant differences in nutrient contents across production types and that all systems are exposed to the same sources of contamination of trace elements to cultivated soil (e.g. irrigation water Koumolou et al. 2013; Djouaka et al. 2016), location close to garbage dumps and intensive traffic, as well as poor agricultural practices regarding fertilisers and pesticides (Atidegla 2018), values from reference literature were retained for $\mathrm{Pb}, \mathrm{Cd}$ and $\mathrm{As}$ for vegetables other than tomato. Data for carrot (Djouaka et al. 2016) correspond to southern Benin - Koumolou et al. (2013) data were not retained due to aberrant values for As, likely due to the chosen analytical methods. All retained values are presented in Table 3. The more detailed focus on tomatoes and carrots is justified by the relative higher importance of these two crops in terms of consumer preferences, interesting nutritional features, dry matter content and production volumes. 
Table 3 Mean content of trace nutrients and contaminants (trace elements) in tomato and carrot samples from southern Benin

\begin{tabular}{|c|c|c|c|c|c|c|c|}
\hline & \multirow[t]{2}{*}{$/ 100 \mathrm{~g}$} & \multicolumn{3}{|l|}{ Carrot } & \multicolumn{3}{|l|}{ Tomato } \\
\hline & & Organic & Conventional & Lean & Organic & Conventional & Lean \\
\hline DM & g & 8.9 & 8.9 & 8.9 & 5.5 & 5.5 & 5.5 \\
\hline Dietary fibre & $\mathrm{g}$ & $3.2^{\mathrm{a}}$ & $3.2^{\mathrm{a}}$ & $3.2^{\mathrm{a}}$ & $1.4^{\mathrm{a}}$ & $1.4^{\mathrm{a}}$ & $1.4^{\mathrm{a}}$ \\
\hline Polyphenols & $\mathrm{mg}$ & 762 & 896 & 1537 & 1720 & 2691 & 2565 \\
\hline$\beta$-Carotene & $\mu \mathrm{g}$ & 3313 & 4028 & 6040 & 2922 & 3633 & 3255 \\
\hline Vitamin B12 & $\mu \mathrm{g}$ & $<0.3$ & $<0.3$ & $<0.3$ & $<0.3$ & $<0.3$ & $<0.3$ \\
\hline $\mathrm{Ca}$ & $\mathrm{mg}$ & 25.37 & 31.57 & 26.20 & 11.97 & 13.95 & 9.46 \\
\hline $\mathrm{Fe}$ & $\mathrm{mg}$ & 2.37 & 3.91 & 2.52 & 3.40 & 3.46 & 2.97 \\
\hline $\mathrm{Mn}$ & $\mathrm{mg}$ & 4.01 & 1.39 & 2.60 & 0.73 & 0.76 & 0.69 \\
\hline $\mathrm{Zn}$ & $\mathrm{mg}$ & 6.21 & 4.83 & 4.65 & 2.51 & 2.33 & 2.30 \\
\hline $\mathrm{Pb}$ & $\mathrm{mg}$ & $3.68 \mathrm{E}-3^{\mathrm{b}}$ & $3.68 \mathrm{E}-3^{\mathrm{b}}$ & $3.68 \mathrm{E}-3^{\mathrm{b}}$ & $1.35 \mathrm{E}-02$ & 8.89E-01 & $4.45 \mathrm{E}-01^{\mathrm{c}}$ \\
\hline $\mathrm{Cd}$ & $\mathrm{mg}$ & $6.40 \mathrm{E}-4^{\mathrm{b}}$ & $6.40 \mathrm{E}-4^{\mathrm{b}}$ & $6.40 \mathrm{E}-4^{\mathrm{b}}$ & $1.01 \mathrm{E}-01$ & 7.52E-02 & $6.33 \mathrm{E}-02$ \\
\hline As & $\mathrm{mg}$ & $1.00 \mathrm{E}-6^{\mathrm{b}}$ & $1.00 \mathrm{E}-6^{\mathrm{b}}$ & $1.00 \mathrm{E}-6^{\mathrm{b}}$ & $1.21 \mathrm{E}-02$ & 7.59E-03 & 4.22E-03 \\
\hline
\end{tabular}

$D M$ dry matter

${ }^{a}$ Values taken from Vincent et al. (2020)

${ }^{\mathrm{b}}$ Values taken from Djouaka et al. (2016)

${ }^{c}$ Value estimated as half of that for Conventional, because measurements were below detection limits
Based on the reference values listed in Table 4, and the nutrients and contaminants values detailed in Table 3 , we computed the nutritional indices as depicted in Fig. 3 $\left(\mathrm{NRF}_{8.4}=\mathrm{NRF}_{8}-\mathrm{LIM}_{4}\right)$. For $\mathrm{NRF}_{8}$ and $\mathrm{NRF}_{8.4}$, the larger the index is, the better the nutrition delivered is. For $\mathrm{LIM}_{4}$, the smaller the index is, the lower the negative contribution of substances to limit is. Lean carrots and Organic tomatoes feature the highest nutritional scores for each crop, mostly driven by higher $\beta$-carotene content (carrots) and lower $\mathrm{Pb}$ content (tomatoes). An alternative computation

Table 4 Reference intake values for trace nutrients and contaminants (trace elements)

\begin{tabular}{llll}
\hline & Unit/day & MRV $^{\mathrm{a}}$ & $\mathrm{DV}^{\mathrm{b}}$ \\
\hline Dietary fibre & $\mathrm{g}$ & & 30 \\
Polyphenols & $\mathrm{mg}$ & & $500^{\mathrm{c}}$ \\
B-Carotene & $\mu \mathrm{g}$ & & 700 \\
Vitamin B12 & $\mu \mathrm{g}$ & & 2.4 \\
$\mathrm{Ca}$ & $\mathrm{mg}$ & & 900 \\
$\mathrm{Fe}$ & $\mathrm{mg}$ & & 12.5 \\
$\mathrm{Mn}$ & $\mathrm{mg}$ & & 390 \\
$\mathrm{Zn}$ & $\mathrm{mg}$ & 0.3 & 11 \\
$\mathrm{~Pb}$ & $\mathrm{mg}$ & 0.05 & \\
$\mathrm{Cd}$ & $\mathrm{mg}$ & 0.1 & \\
$\mathrm{As}$ & $\mathrm{Mg}$ & & \\
\hline
\end{tabular}

Energy densities of carrot and tomato were determined at 34 and $22 \mathrm{kcal} / 100 \mathrm{~g}$, respectively, following Vincent et al. (2020). MRV daily maximum recommended values, $D V$ daily values

${ }^{a}$ Koumolou et al. (2013) and FAO/WHO (2015)

${ }^{\mathrm{b}}$ Maillot et al. (2007)

${ }^{\mathrm{c}}$ Martin (2009) of the nutritional indices $\left(\mathrm{NRF}_{8^{\prime} 0.3}=\mathrm{NRF}_{8},-\mathrm{LIM}_{3}\right)$, which excludes "excess" polyphenols as a nutrient to limit, was also computed for comparison. In this second case, the same trend across crops and types is observed, but $\mathrm{NRF}_{n . m}$ is higher due to polyphenol contents.

\subsection{Life cycle inventories}

Primary data were collected for three sites: Houéyiho (Cotonou), Ouidah and Sèmè-Kpodji. The crops for which primary data were collected are carrots (Ca), tomatoes (To), leafy vegetables such as lettuce (Lf) and the Cucurbitaceae cucumber and watermelon $(\mathrm{Cu})$ (see survey distributions across sites, production types and crops in the Supplementary Material). The rotations practiced at these sites are very diverse, but the most common are the successions $\mathrm{Lf} \rightarrow \mathrm{Lf} \rightarrow \mathrm{Lf} \rightarrow \mathrm{Lf}$ and $\mathrm{Lf} \rightarrow \mathrm{Ca} / \mathrm{Cu} / \mathrm{To} \rightarrow$ Lf. A few fallow reversals were also observed.

Direct $\mathrm{N}$ emissions, which are considered to be amongst the most significant contributors to agricultural LCA impacts, differed amongst sites, crops and production types. For instance, $\mathrm{N}$ emissions from Conventional crops in SèmèKpodji appear to be the highest, except for nitrate fluxes, which are highest in Ouidah (Table 5). Nitrate leaching losses appear to be close to zero in most cases, which is compatible with measurements in dry tropical environments (Diallo et al. 2019). In humid tropical environments, since the soil texture is sandy and the crops studied occur outside the drainage season, the estimated values appear to be correct (Feder et al. 2015).

Based on the inputs of fertilisers and phytosanitary products (Table 5), there appear to be differences in intensity 
Fig. 3 Nutritional indices (Nutrient Rich Food and LIMited nutrients score) for southern Benin carrot and tomato: a) featuring excess polyphenols as a nutrient to limit and $\mathbf{b}$ ) featuring polyphenols only as a desirable nutrient a)

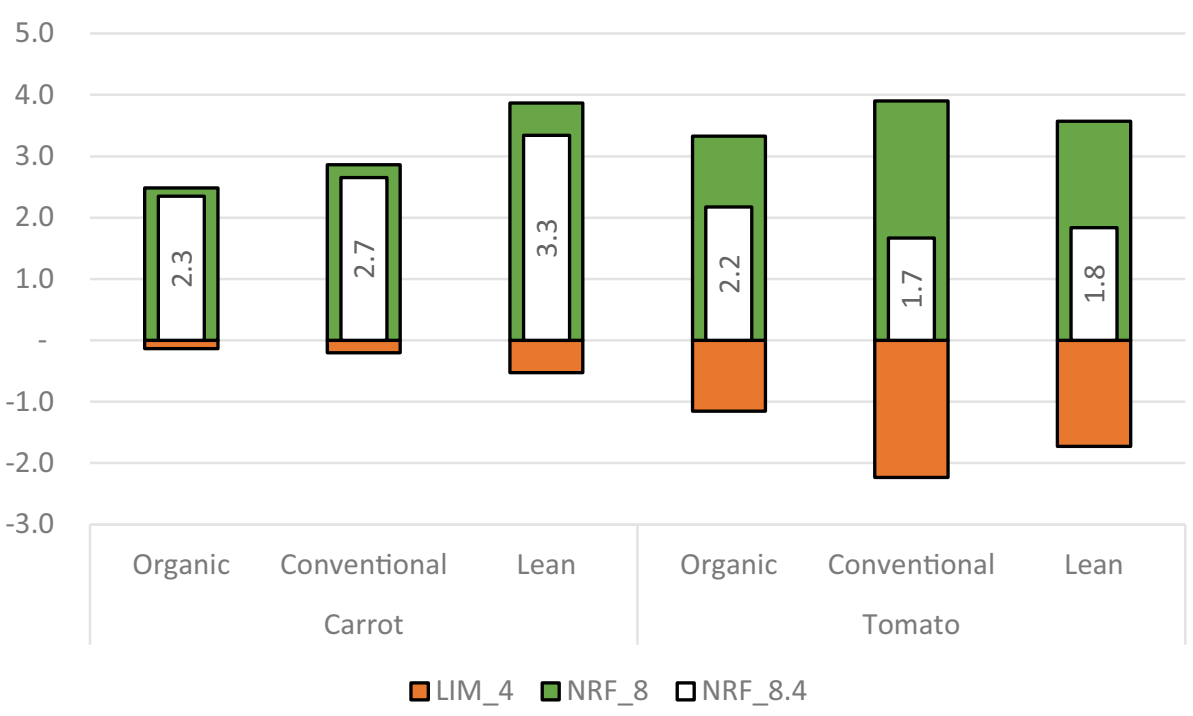

b)

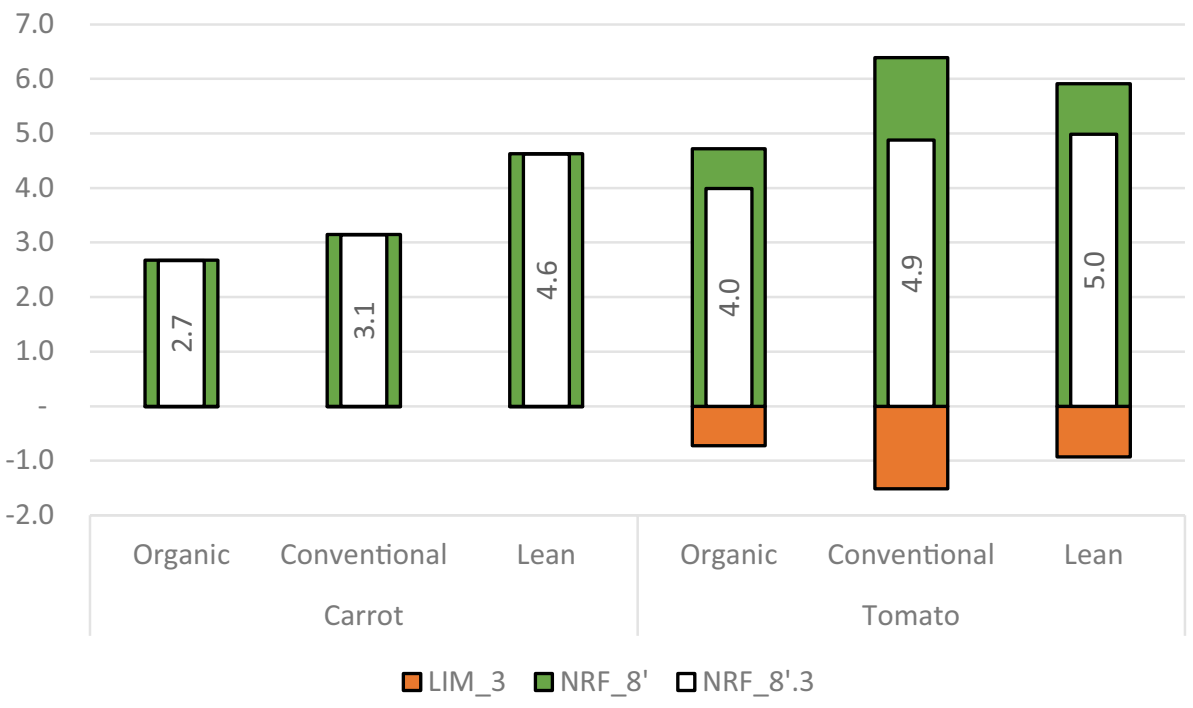

between sites, crops and production types. For instance, the intensity of synthetic fertilisers use in Conventional crops is higher for Ouidah, and that of organic fertiliser is higher for Sèmè-Kpodji. The intensity of phytosanitary measures is higher for Organic products in Sèmè-Kpodji, and this site has the highest input intensity for all crops and production types.

Detailed inventories per production unit, including disaggregated yields, are presented in the Supplementary Material. Yields in Benin are within West African orders of magnitude, whilst the yield gap between organic and conventional production is within the global estimated gap of $80 \%$ (de Ponti et al. 2012). For instance, Benin Conventional tomato yields reach in average $6.0 \mathrm{t} / \mathrm{ha}$, Lean $2.2 \mathrm{t} / \mathrm{ha}$ and Organic 9.5 t/ha, whilst FAOSTAT (FAO 2019b) 2018 reported mean yields in Western Africa reached $7.2 \mathrm{t} / \mathrm{ha}$ in and in the whole of Africa 16.1 t/ha (the latter driven by much higher yields in northern and southern Africa).

\subsection{Life cycle impact assessment: endpoints}

By analysing the results by single score (i.e., all impact categories normalised and combined), differences between sites and production types are noticeable, with Organic crops and products from Sèmè-Kpodji having systematically higher impacts, both per $\mathrm{kg}$ of produce and per ha of cultivation (Fig. 4). For all crops and sites combined, Organic production features the highest scores (Fig. 4c). The impact per $\mathrm{kg}$ of products is ten times higher than for the Conventional and Lean production. However, per ha, the impact of Organic is higher: twice as high as for Conventional and six times higher than for Lean. Finally, per kg of products, Lean and Conventional production feature similar scores. On the other hand, per ha, impacts are three times higher for Conventional than for Lean production. Organic production have different impacts for the two concerned sites. Per kg 
Table 5 Mean values for fertiliser, yields, phytosanitary inputs to and direct $\mathrm{N}$ emissions from market vegetable gardening products from southern Benin, per site and production type, computed with Indigo-N v2.7 over the crop rotation

\begin{tabular}{|c|c|c|c|c|c|c|}
\hline Houéyiho & Ouidah & & & Sèmè-Kpoc & & \\
\hline Conventional & $\begin{array}{l}\text { All production Organic } \\
\text { types }\end{array}$ & Conventional & Lean & $\begin{array}{l}\text { All } \\
\text { production } \\
\text { types }\end{array}$ & Organic & Conventional \\
\hline
\end{tabular}

\begin{tabular}{|c|c|c|c|c|c|c|c|c|}
\hline \multicolumn{9}{|l|}{ Emission $(\mathrm{kg} / \mathrm{ha})$} \\
\hline $\mathrm{NH}_{3}$ & 25.25 & 35.62 & 50.21 & 49.02 & 5.89 & 60.13 & 50.38 & 68.49 \\
\hline $\mathrm{N}_{2} \mathrm{O}$ & 4.21 & 5.86 & 8.06 & 8.12 & 1.16 & 10.10 & 9.14 & 10.91 \\
\hline $\mathrm{NO}_{\mathrm{x}}$ & 0.88 & 1.23 & 1.69 & 1.71 & 0.24 & 2.12 & 1.92 & 2.29 \\
\hline $\mathrm{NO}_{3}$ & 1.37 & 2.04 & 2.38 & 2.00 & 1.65 & 1.02 & 0.42 & 1.53 \\
\hline \multicolumn{9}{|l|}{ Inputs per ha } \\
\hline Mineral fertilisers (kg) & 152 & 77 & 0 & 196 & 64 & 86 & 0 & 160 \\
\hline Organic fertilisers $^{\mathrm{a}}(\mathrm{kg})$ & 3831 & 7659 & 11,380 & 8403 & 2452 & 14,118 & 16,716 & 11,892 \\
\hline Phytosanitary substances (g) & 7988 & 3099 & 4093 & 4367 & 756 & 65,596 & 133,637 & 7275 \\
\hline Yields (t/ha) & 32.6 & 13.3 & 11.4 & 17.9 & 11.4 & 21.9 & 20.1 & 22.3 \\
\hline
\end{tabular}

"Organic fertilisers" include organic amendments

of products, impacts are five times higher in Sèmè-Kpodji than in Ouidah. However, per ha, it is only 1.8 times higher. For all crops and all sites combined, the conventional production shows small differences amongst the three sites. Per $\mathrm{kg}$ of products and per ha, the single score in Houéyiho is 2 to 3 times lower than in Sèmè-Kpodji, whilst Ouidah features intermediate single scores. Lean production cannot be properly compared across sites, as it has only been studied at Ouidah. However, it has the lowest single score per ha, whilst per kg of product, its single score is twice as high as that of conventional production in Houyiho, the lowest of all. All crops combined, the single score averages per site show significant differences ( $p$-value $<0.003$, except for the non-significant pair Oiudah-Houéyiho; see Fig. 2 in the Supplementary Material): 3 to 20 times higher in Sème-Kpodji than in Houyiho, respectively, per ha and per kg of products. However, not all the production types studied are present at each site, which reduces the relevance of a comparison of averages.

Statistical processing of the results allows preliminary findings to be refined, taking into account the variability amongst production units (see R outputs for Tukey's pairwise comparisons per crop, fertilisation strategy and site in Fig. 2 in the Supplementary Material):

- For carrot, there are significant differences (p value $<0.04$ ) between the impacts of Organic vs. Conventional and Lean, but not between Conventional and Lean. There are furthermore significant differences ( $p$ value $=0.004)$ between the aggregated impacts of the products from Sèmè-Kpodji and Houéyiho. An outlier value has been identified in Houéyiho: a carrot production unit without organic matter inputs.
- For tomatoes, there are no significant differences (p-value $>0.05$ ) between the impacts, either by production type, by site and even by variety, despite an Organic outlier in Sèmè-Kpodji featuring very high organic matter inputs, and three Organic tomato production units, also in Sèmè-Kpodji, with very low yields, intended for selfconsumption.

- For cucumber, there are no significant differences (p-value $>0.05$ ) in impacts, either by production type, by site or even by variety, despite the outlier value of a Conventional unit at Sèmè-Kpodji with low organic matter inputs. - For lettuce, there are significant differences (p-value $<0.008$ ) between the aggregate impacts of Houéyiho products and other sites, but not between Organic and Conventional impacts.

- For watermelon, there are no significant differences (p-value $>0.05$ ) between impacts by production type (data available for a single site).

- For all crops, there are significant differences (p-value $<0.001$ ) between the impacts of Organic vs. Conventional and Lean, but not between Conventional and Lean. There are moreover significant differences (p-value $<0.003$ ) between the aggregate impacts of Sèmè-Kpodji's products and other sites, due to the high organic matter inputs featured by several production units.

- For each crop and for the all production units, no correlation between yields and impacts was found.

The statistical propagation of data uncertainty was not possible because we did not obtain sufficient uncertainty data. Nevertheless, contribution analyses per production type were carried out. For instance, for tomatoes, the impacts of Conventional and Organic are dominated by direct field 


\section{a) All crops, per site}

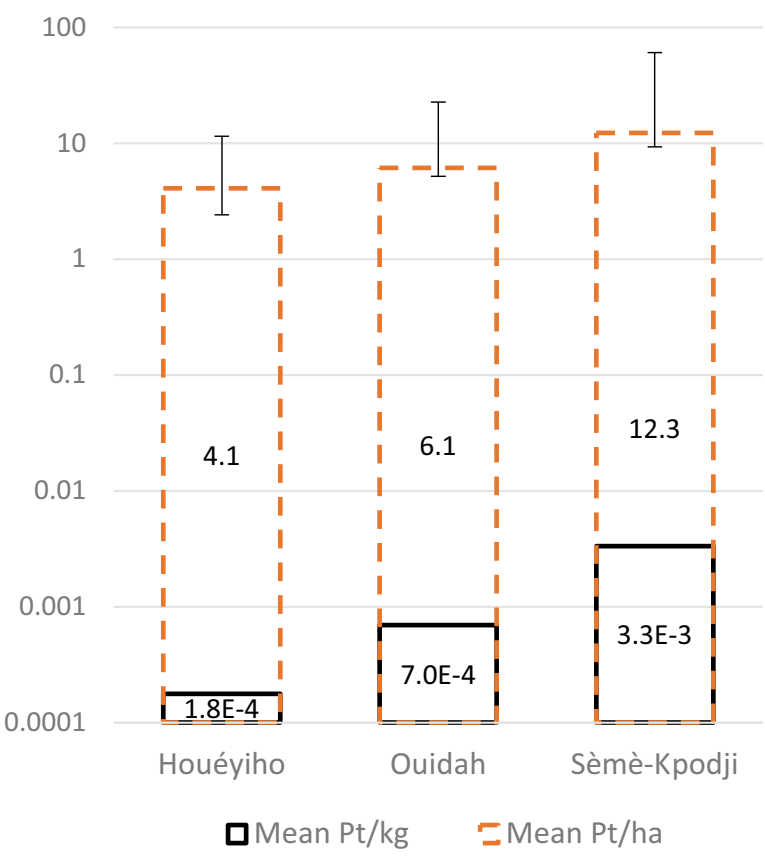

b) All crops, per production type

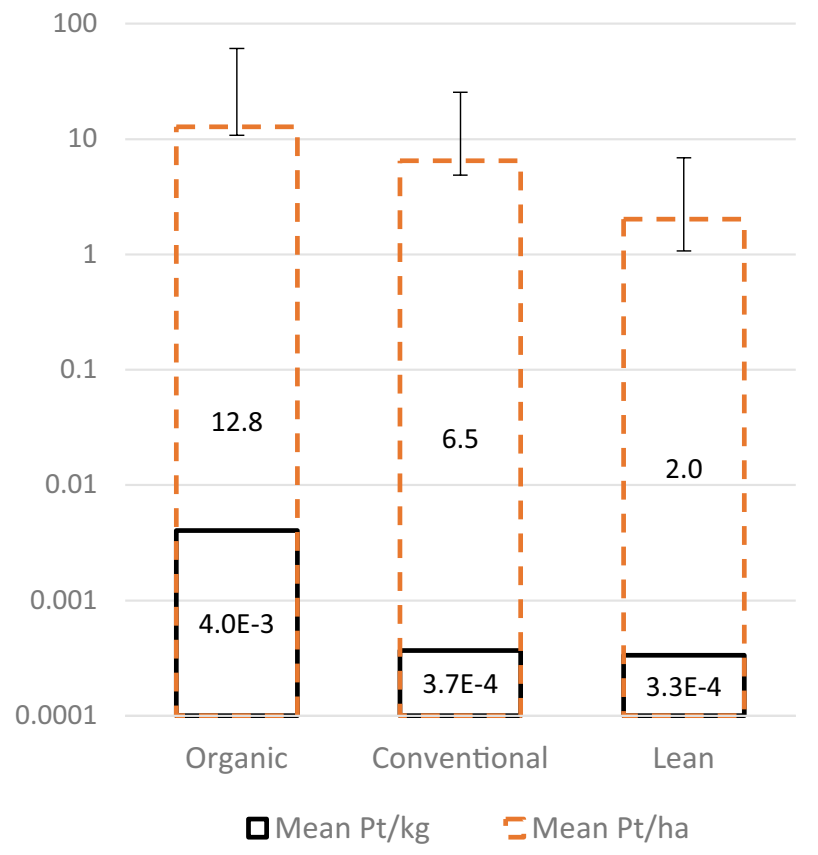

c) All crops, per site and production type

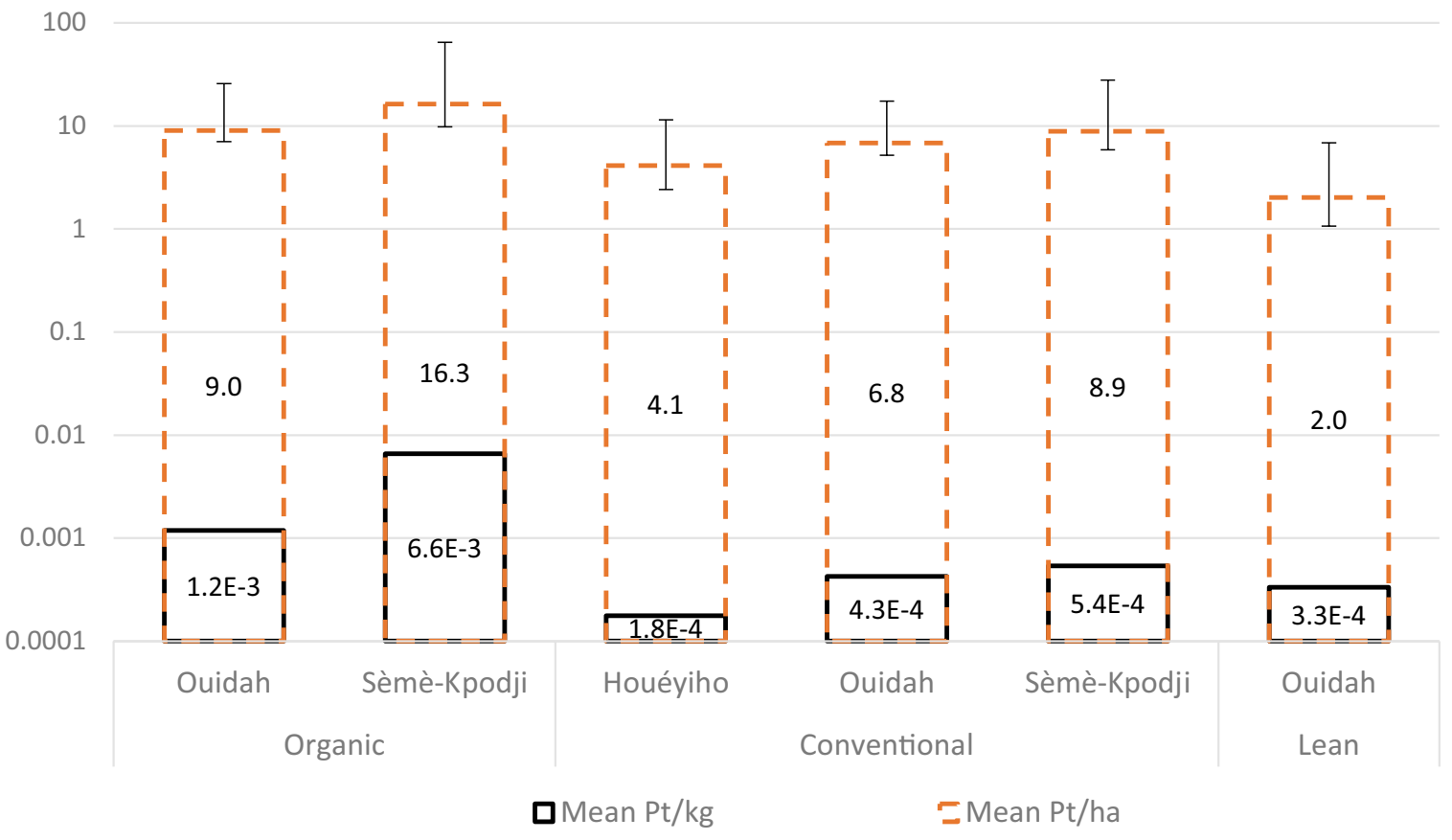

Fig. 4 Mean impacts (single ILCD score, in Pt) of the sites and production types of four market vegetable gardening products in southern Benin, per $\mathrm{kg}$ of product and per ha of crop (error bars represent the variation amongst production unit values contributing to the mean)

emissions (nitrogen and trace elements). For Organic production, the contribution of fuels is slightly lower, but the overall distribution of contributions remains similar. Moreover, there are few differences between self-consumption and commercial production. Impacts of Lean systems are dominated by fuel consumption (e.g. for irrigation), due to the lower contribution of fertilisation (Fig. 5).

In addition, the sensitivity of impacts to inputs can be illustrated by the comparison between Lean, Organic and Conventional tomatoes, whose input intensity increases in 
Fig. 5 Contribution analysis of tomato, based on the single ILCD score per $\mathrm{kg}$ of product, all sites combined

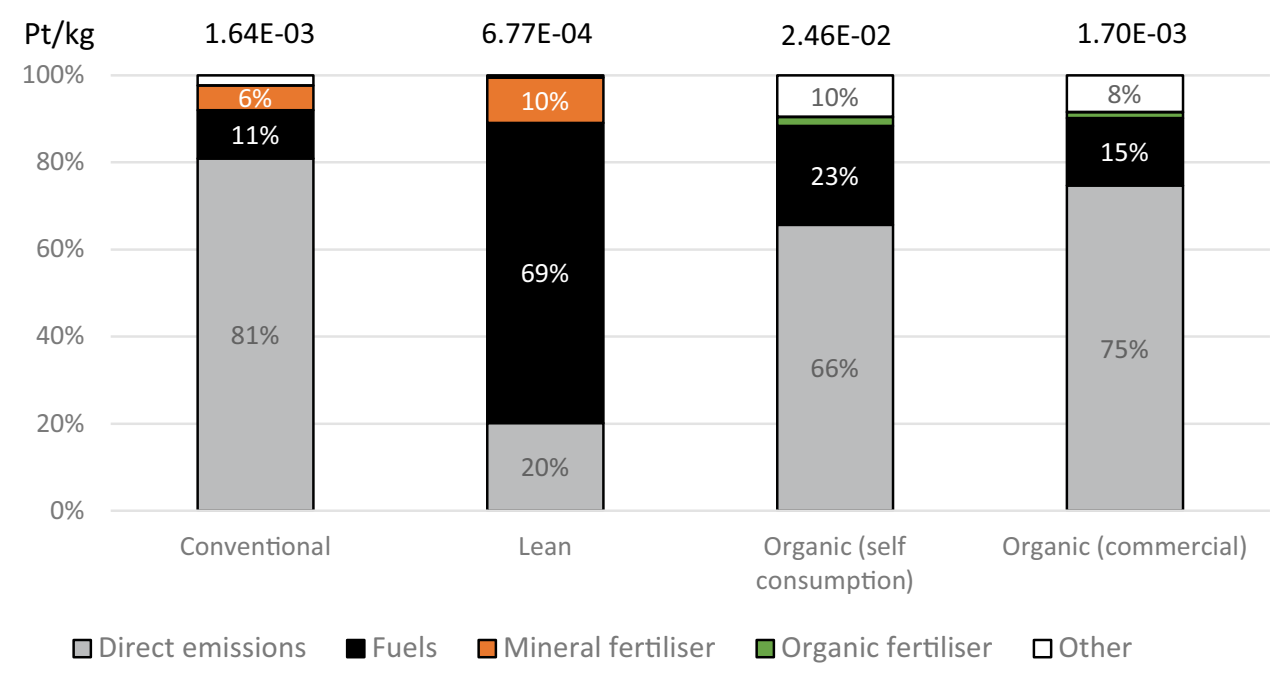

that order (Fig. 6). All sites combined, the yields per ha of Lean tomato production were 4 times lower than in Conventional production. However, the impacts were 8 times and 2 times less per ha and per quantity of product, respectively.
The impacts of the different nitrogen emissions have always been very low for Lean production since they represented at most $5 \%$ of those of conventional production. Similarly, in Lean production, the absence of the use of phytosanitary
Fig. 6 Comparisons of the inputs and impacts of one example of a tomato system from each production type

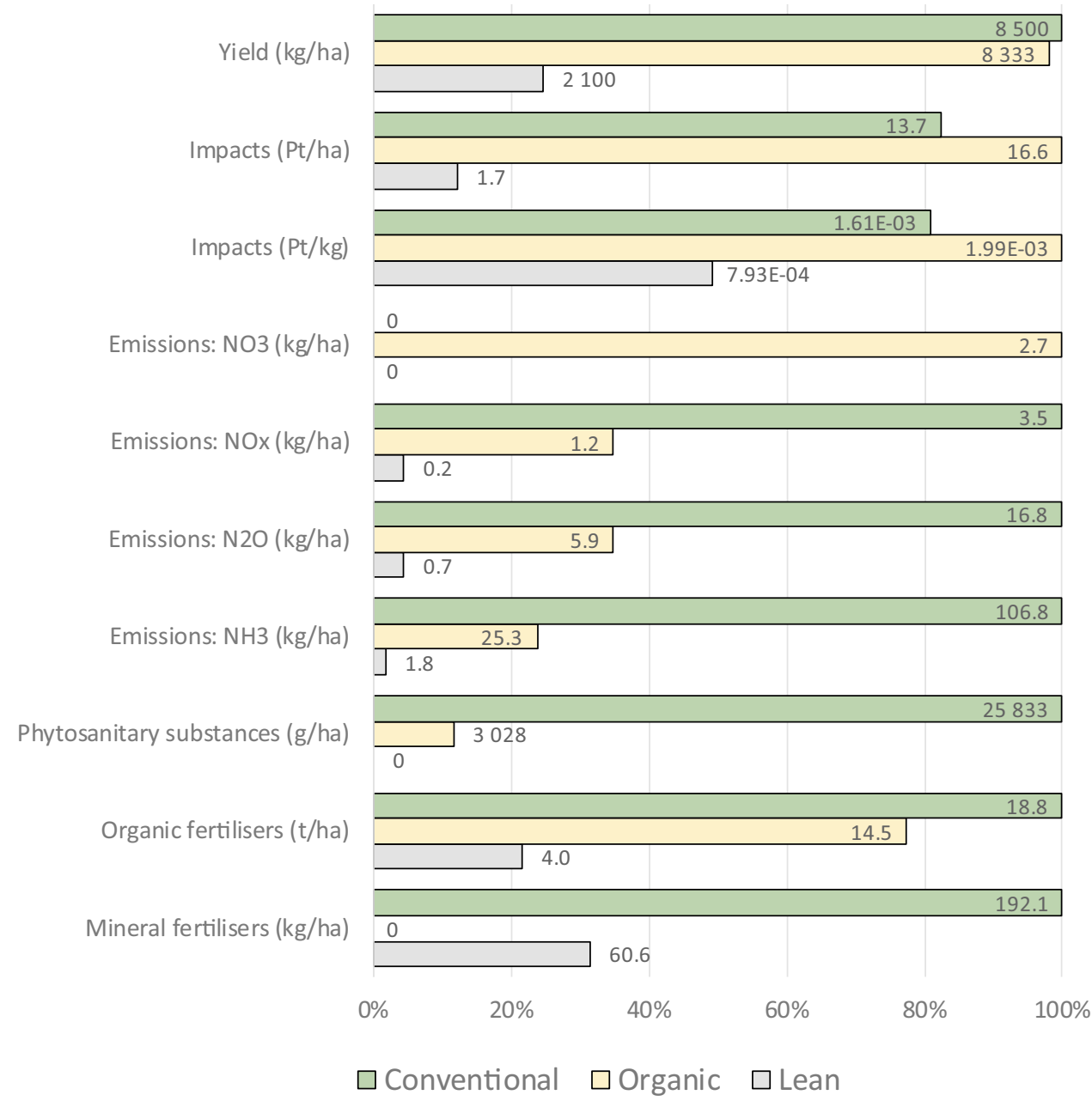


substances and the use of three times less mineral fertilisers have contributed to significantly lower impacts per ha.

\subsection{Life cycle impact assessment: midpoints and comparison with other studies}

When the environmental impacts are expressed as midpoints, such as $\mathrm{kg} \mathrm{CO}_{2}$-eq for climate change, they vary noticeably amongst production types and sites. These impacts are related to input intensities, particularly fertilisation. Detailed midpoint scores per production unit are presented in the Supplementary Material.

Contribution analyses on four key impact categories, at the midpoint level, show that the dominant contributors to impacts vary according with the specific impact category: energy for climate change (Fig. 7a), direct field emissions for eutrophication (Fig. 7b) and acidification (Fig. 7c) and a combination of pesticides, mineral fertilisers, energy and direct field emissions for freshwater ecotoxicity (Fig. 7d).

Lean production showed a lower overall impact regarding energy for climate change (Fig. 7a) than Conventional and Organic production per ha. A rational use of mineral fertilisers in Lean production had a lower impact than organic-only fertilisation; this despite higher impacts for energy use in Lean production (92.4\%) than in Organic production $(60.4 \%)$. Nevertheless, the comparison inter sites showed a more heterogeneous and complex situation, since the Houéyiho site, with Conventional production only, presented slightly less impact than the Sèmè-Kpodji site, which mixed Conventional and Organic production. It was the impact of organic fertilisation that changed this order.

The impact on freshwater eutrophication (Fig. 7b) showed the same distribution. Thus, Lean production showed the lowest impacts and Conventional production the highest impacts, but it was the Sèmè-Kpodji site that had the highest impacts. Apart from the impact of mineral fertilisers, it was all the other non-detailed factors contributing to impacts that changed the order.

The impacts on acidification (Fig. 7c) and on freshwater ecotoxicity (Fig. 7d) followed the same order. Lean production had significantly lower impacts than Conventional and Organic production for these two impact categories. The latter had the highest impacts because of organic fertilisers and direct emissions (for acidification), direct emissions and other non-detailed factors (for freshwater ecotoxicity). Non-detailed factors to impacts include a very long series of a)

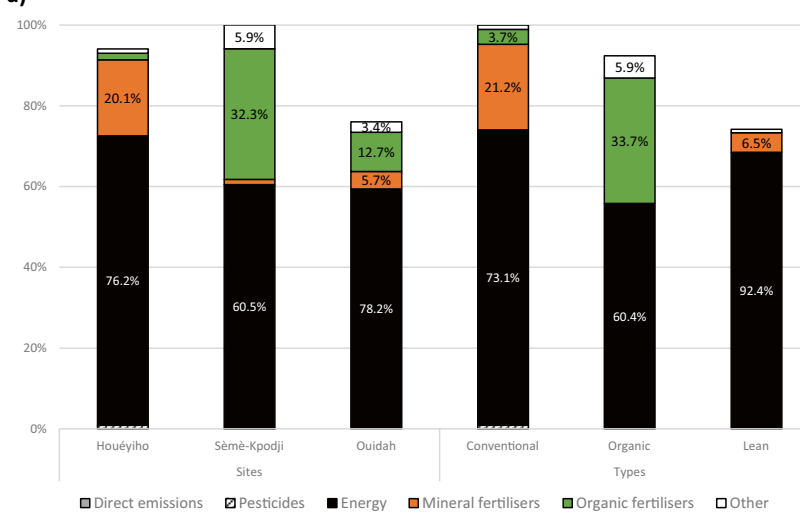

c)

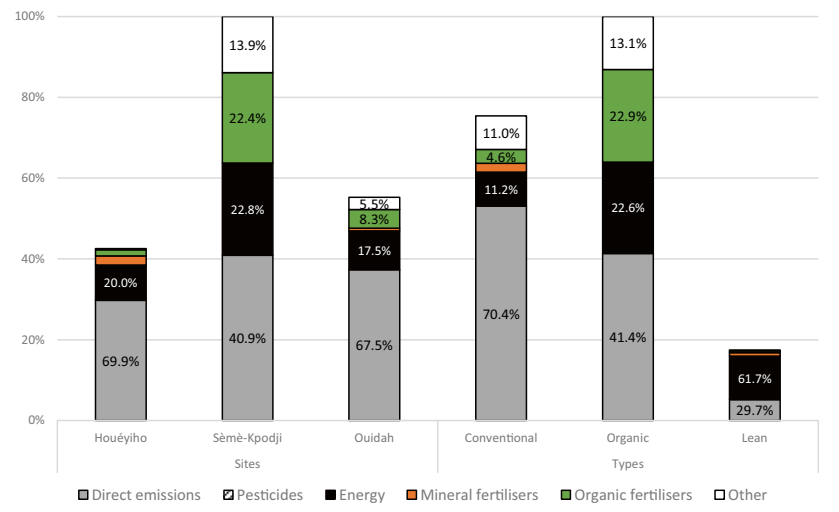

b)

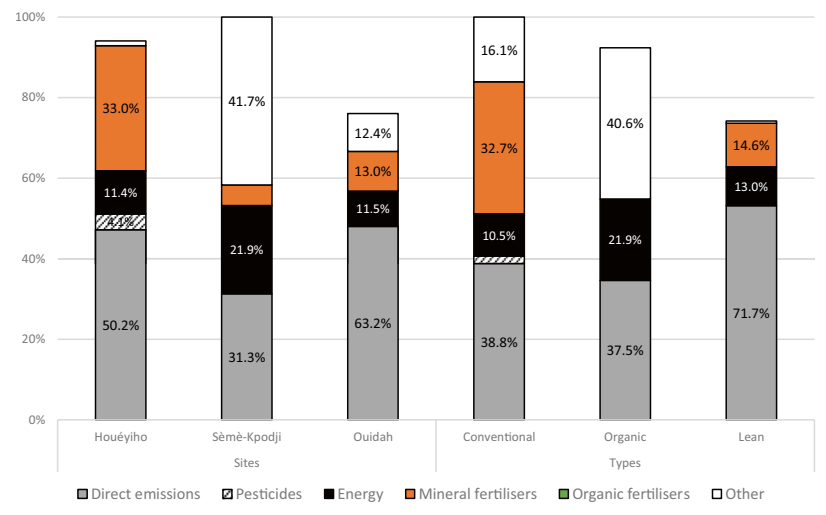

d)

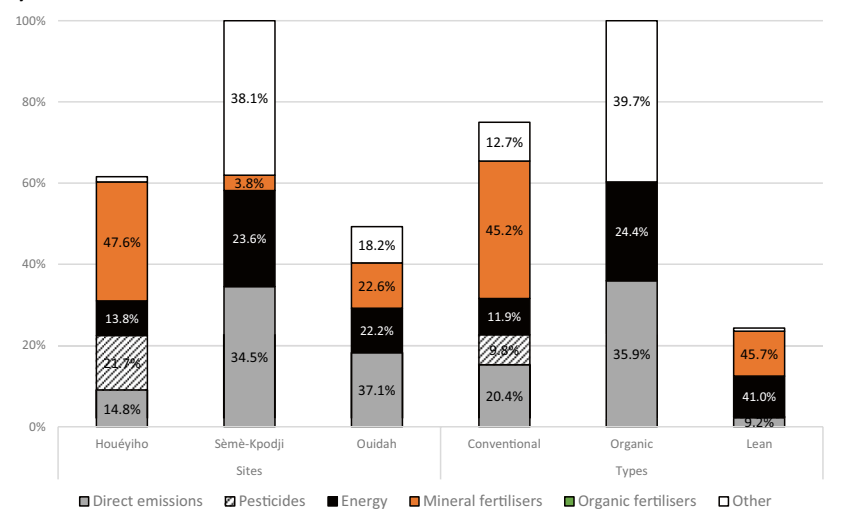

Fig. 7 Contribution analysis of all crops, per ha of cultivation, per sites and production types, for a) climate change, b) freshwater eutrophication, c) acidification and d) freshwater ecotoxicity 
elementary flows (associated for instance with background data such as the provision of industrial inputs) with very small contributions, but which one aggregated, become non-negligible.

Our results suggest consistently higher climate change impacts for Organic production per kg of product and for Conventional production per ha of crop. A priori, we speculated that these results are due to lower yields and high quantities of organic fertilisers used in organic market gardening. The high impacts of Sèmè-Kpodji's organic tomatoes are due to the fact that several production units are not commercial, but systems intended for self-consumption, with very low yields. In LCA, there is demonstrable link between input intensity (e.g. fertilisation) and yields and direct field emissions, which are usually determinant of impacts per functional unit (be it expressed in a mass or a surface unit).

A comparison of the climate change results of this study with overall results reported in the literature suggests that the impacts of market vegetable gardening in southern Benin (average of all products and production types ranging from 0.21 for Houéyiho to 2.56 for Sèmè-Kpodji, with an average of $1.24 \mathrm{~kg} \mathrm{CO}_{2}$-eq $/ \mathrm{kg}$ produced) are in the same order of magnitude as other values reported for vegetable crops (Table 6). For example, Perrin (2013) estimated $3.08 \mathrm{~kg} \mathrm{CO}_{2}$-eq per $\mathrm{kg}$ of conventional Beninese off-season tomatoes, whilst we found a value (mean of Conventional and Lean, comparable with systems in Perrin (2013)) of $1.32 \mathrm{~kg} \mathrm{CO}_{2}$-eq per $\mathrm{kg}$ of seasonal tomatoes.

An environmental and economic study on market vegetable gardening in the Niayes region of Senegal found that conventional systems are more profitable than organic ones, due to lower yields of the latter and the minor size of the organic food market (Binta and Barbier 2015). It also found that land use is similar, if relatively higher for the conventional systems, and that GHG emissions are higher as well for the conventional systems. The situation in Benin seems to be very similar.

\subsection{Interpretation: endpoints, midpoints and nutritional aspects}

Yields from organic systems are generally lower than those of conventional ones, the so-called organic/conventional yield gap (de Ponti et al. 2012; Ponisio et al. 2015). It is has been suggested that the closing of this gap is a matter of time, as soil properties and processes, highly contributing to yield, change at a very slow pace (Schrama et al. 2018). Certain crops such as tomato exhibit no significant difference in yield resulting from organic and conventional fertilisation regimes (Tonfack et al. 2009; He et al. 2016),
Table 6 Comparison of the impacts of climate change reported in the literature

\begin{tabular}{|c|c|c|c|}
\hline \multirow{3}{*}{$\begin{array}{l}\text { Products (at farm gate) } \\
\text { Carrot (Conventional) }\end{array}$} & Benin & \multicolumn{2}{|c|}{ Other geographies } \\
\hline & \multicolumn{3}{|c|}{ Climate change ( $\mathrm{kg} \mathrm{CO}_{2}$-eq/kg product) } \\
\hline & $0.30^{\mathrm{a}}$ & $0.19^{c}$ & Global \\
\hline Cucumber (Conventional) & $0.41^{\mathrm{a}}$ & $0.72^{\mathrm{c}}$ & Global \\
\hline $\begin{array}{l}\text { Field vegetables: } \\
\text { Conventional } \\
\text { Mean of Conventional, Organic and Lean } \\
\text { Under heated greenhouse } \\
\text { Green beans }\end{array}$ & $\begin{array}{l}1.24^{\mathrm{a}} \\
0.35^{\mathrm{a}}\end{array}$ & $\begin{array}{l}2.03-2.12^{b} \\
0.57^{d}\end{array}$ & $\begin{array}{l}\text { Europe } \\
\text { Kenya }\end{array}$ \\
\hline $\begin{array}{l}\text { Leafy vegetables: } \\
\text { Different production types } \\
\text { Brassicae (cabbage, etc.) } \\
\text { Lettuce (Conventional) }\end{array}$ & $0.16^{\mathrm{a}}$ & $\begin{array}{l}0.80^{\mathrm{c}} \\
0.57^{\mathrm{c}} \\
0.81^{\mathrm{c}}\end{array}$ & $\begin{array}{l}\text { Global } \\
\text { Global } \\
\text { Global }\end{array}$ \\
\hline $\begin{array}{l}\text { Tomato: } \\
\text { Different production types } \\
\text { Different production types } \\
\text { Seasonal, Conventional } \\
\text { Seasonal, mean of Conventional and Lean } \\
\text { Seasonal, mean of Conventional, Organic and Lean } \\
\text { Off-season } \\
\text { Under unheated greenhouse }\end{array}$ & $\begin{array}{l}0.89^{\mathrm{a}} \\
3.08^{\mathrm{a}} \\
4.73^{\mathrm{a}} \\
1.32^{\mathrm{b}}\end{array}$ & $\begin{array}{l}0.89^{\mathrm{b}} \\
1.23^{\mathrm{c}} \\
0.22^{\mathrm{e}}\end{array}$ & $\begin{array}{l}\text { Europe } \\
\text { Global } \\
\text { Morocco }\end{array}$ \\
\hline Watermelon (Conventional) & $0.08^{a}$ & $0.38^{\mathrm{c}}$ & Australia \\
\hline \multicolumn{4}{|l|}{${ }^{\mathrm{a}}$ This study } \\
\hline \multicolumn{4}{|l|}{${ }^{\mathrm{b}}$ Perrin (2013) } \\
\hline \multicolumn{4}{|l|}{ cClune et al. (2017) } \\
\hline d Basset-Mens et al. (2019) & & & \\
\hline${ }^{\mathrm{e}}$ Payen et al. (2015) & & & \\
\hline
\end{tabular}


whilst for others such as lettuce, there is a significant difference (e.g. Foteinis and Chatzisymeon 2016). Nevertheless, yield is not a good predictor of environmental impact (as shown in the statistical analyses presented in the Supplementary Material), as the latter is driven by a combination of factors both pertaining to and external to the agricultural system and its management (Meier et al. 2015). Statistically significant differences in impacts were found in this study amongst production sites (for carrot, lettuce and all crops) and production types (for carrot and all crops). For crops such as tomato, produced on all sites, under all production types, and using multiple crop varieties, the natural and management-driven variability is large enough that no significant differences were found. The lack of differences in environmental impacts for tomato, cucumber and watermelon production across production types confirms previous findings (e.g. He et al. 2016). For other vegetables such as leafy vegetables and carrots, we found that the impacts are statistically different across types, in alignment with previous studies (e.g. Kowalczyk and Cupiał 2020). It can thus be stated that, based on the whole sample of production units (representative of the population of southern Benin producers, according with local experts from the University of Abomey-Calavi), organic production and production carried out at Sèmè-Kpodji feature higher impacts per both mass and area-based functional units. Similar conclusions were reached by previous comparisons regarding the relative impact, per unit of area, of organic vs. conventional vegetables, whilst our results differ from the generalised consensus that organic systems' impact is generally lower per unit of mass (Tuomisto et al. 2012; Foteinis and Chatzisymeon 2016). Moreover, the comparison of organic and conventional systems is complex and often biased, as both types of systems are very different in terms of crop rotations, soil farming history, dependence on imported fertilisers, management strategies including fertilisation and soil works, etc. (Meier et al. 2015; Kirchmann et al. 2016).

Several hotspots were identified, per site and per production type, but also for the overall southern Benin vegetable market gardening activity. For instance, the input of mineral fertilisers and organic matter to soils is generally high, yet amongst the 69 production units inventoried, only two exceeded the recommended dose for mineral fertiliser and five that for organic fertiliser. At any rate, impacts are dominated by direct emissions from fertilisation and by fuel consumption for water pumping.

Despite the absence of significant differences amongst production types regarding the contents of both $\beta$-carotene and polyphenols, the nutritional indices depicted in Fig. 3 suggest at least marginal differences across production types regarding the overall nutritional value of carrot and tomato across production types. Based

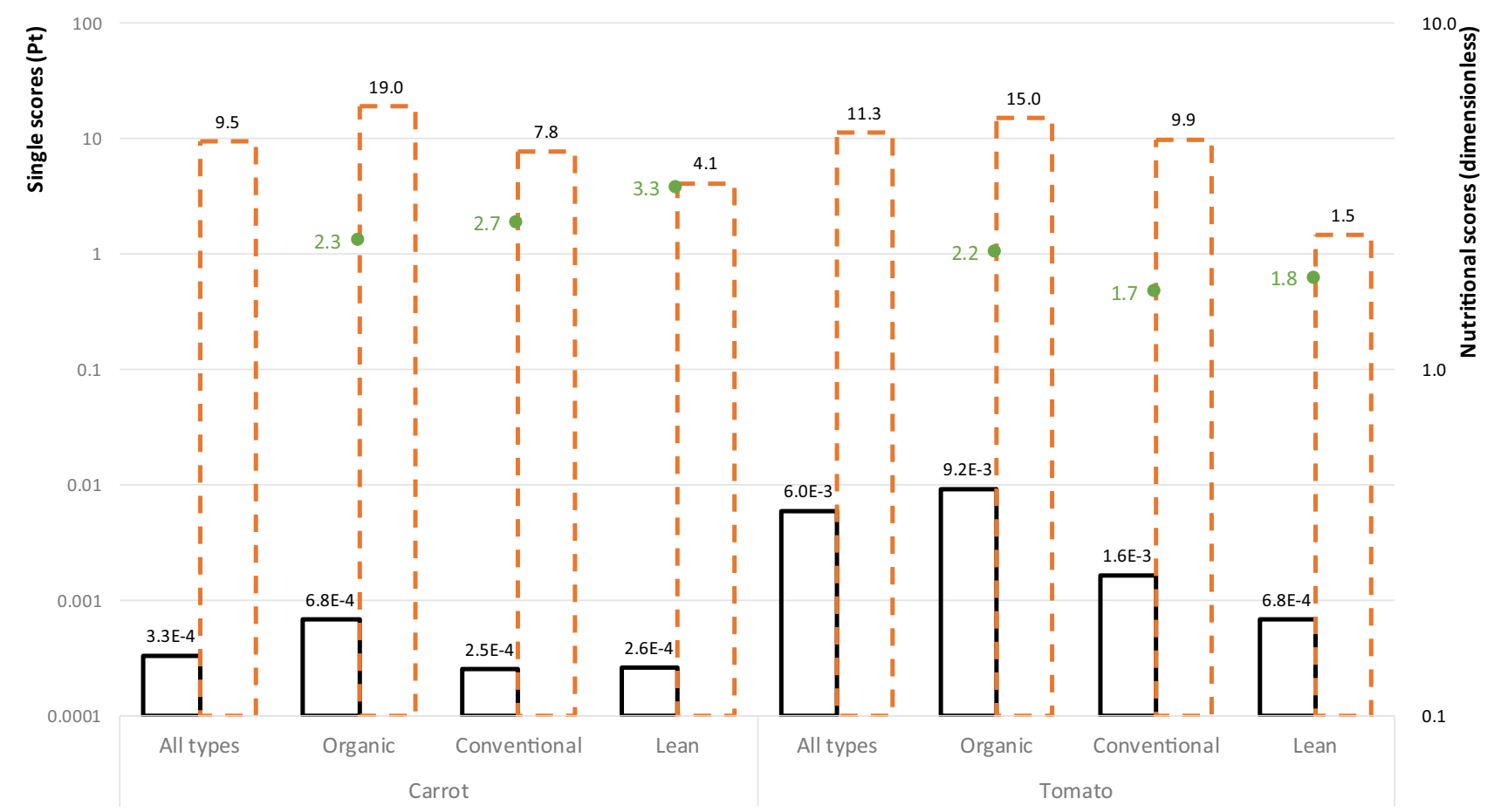

$$
\boldsymbol{D P t} / \mathrm{kg} \quad=\mathrm{Pt} / \mathrm{ha} \quad \circ \mathrm{NRF} \text { 8.4 }
$$

Fig. 8 Mean impacts (single ILCD score, in Pt) across sites of southern Benin carrot and tomato, per kg of product and per ha of crop, contrasted with their associated nutritional indices $\left(\mathrm{NRF}_{8.4}=\right.$ Nutrient Rich Food-LIMited nutrients score $)$ 
on the limited data available, it cannot be stated that such differences are statistically significant. A recent review suggests that, in general terms, the existing evidence does not allow to state that organic food consumption is more beneficial for human health than conventional food intake (Vigar et al. 2020).

For carrot, there seems to be a correlation between nutritional quality and environmental impacts, with higher nutritional scores associated with lower environmental impacts (Fig. 8). For tomato, it does not seem to exist a correlation.

\section{Conclusions}

Based on the environmental and nutritional analyses conducted across the productive continuum of market gardening in southern Benin, which we consider representative of the southern Benin market vegetables production sector, we were able to determine that significant differences existed amongst production types. The larger environmental impacts were associated with Organic production, driven by high inputs and low yields, whilst no statistically significant differences on nutritional quality could be demonstrated across production types. Environmental impacts are dominated by direct emissions from fertilisation (associated with overfertilisation) and by fuel consumption for water pumping. In general, impacts are within the same orders of magnitude of comparable values from other African and global systems, within the limits imposed by pedoclimatic conditions. Nutritional scores are dominated by high levels of $\beta$-carotene and polyphenols, whilst contents of toxic trace elements remain below recommended limits.

Overall improvement of these systems would be achieved by a more technically coherent fertilising strategy, because over-fertilisation is prevalent (by means of poorly understood organic amendments and fertilisers) whilst yields are not higher than the mean yields for Africa. In the African context, it has been suggested that technical efficiency increases with farm size (e.g. Srinivasulu et al. 2015), but other strategies for smallholders have been as well proposed to promote yield increase, such as conservation agriculture (e.g. Thierfelder et al. 2013), more effective fertilisers (e.g. designed, enriched) and fertilising strategies (e.g. dosage, combinations, timing, application technology) (e.g. Bindraban et al. 2015). In any case, smallholders have been shown to provide greater nutritional diversity than larger, often monocrop systems, and are highly relevant food production systems in the SubSaharan African context (Herrero et al. 2017).

Thus, public agricultural policies in Benin could benefit from the evaluation of these impacts by promoting, for example the development of (i) less energy-intensive irrigation, (ii) organic waste processing platforms to reduce volatilisation losses, (iii) knowledge on the fertilising value of organic waste and (iv) agricultural extension services or technical guides on good agricultural practices to reduce over-fertilisation and other negative environmental impacts. All the combination of different tools makes it possible to produce more profitably whilst reducing the pressure on the environment and preserving natural resources (water, fossil energy, mineral elements, etc.). Finally, it has been suggested that improving the use efficiency of agricultural inputs would reduce environmental impacts of food production greatly than a generalised shift from conventional to organic practices (Clark and Tilman 2017).

Supplementary information The online version contains supplementary material available at https://doi.org/10.1007/s11367-021-01977-z.

Acknowledgements We thank all our colleagues and students for their contribution to the research synthesised in this work. We acknowledge the Analytical Means Laboratory (LAMA) of the International Mixed Laboratory Ecological Intensification of Cultivated Soils in West Africa, in Dakar (https://imago.ird.fr/moyens-analytiques/dakar).

Funding The authors were financed by the INRA-CIRAD research programme GloFoodS (https://www.inrae.fr/actualites/securitealimentaire-mondiale-glofoods-devoile-ses-resultats).

Open Access This article is licensed under a Creative Commons Attribution 4.0 International License, which permits use, sharing, adaptation, distribution and reproduction in any medium or format, as long as you give appropriate credit to the original author(s) and the source, provide a link to the Creative Commons licence, and indicate if changes were made. The images or other third party material in this article are included in the article's Creative Commons licence, unless indicated otherwise in a credit line to the material. If material is not included in the article's Creative Commons licence and your intended use is not permitted by statutory regulation or exceeds the permitted use, you will need to obtain permission directly from the copyright holder. To view a copy of this licence, visit http://creativecommons.org/licenses/by/4.0/.

\section{References}

Adékambi SA, Adégbola PYAA (2010) Famers's perception and agricultural technology. The case of botanical extracts and biopesticides in vegetable production in Benin. In: Third African Association of Agricultural Economists (AAAE) and 48th Agricultural Economists Association of South Africa (AEASA) Conference, Cape Town, South Africa, September 19-23, 2010

Agbossou KEE, Sanny MSS, Zokpodo B et al (2003) Evaluation qualitative de quelques légumes sur le périmètre maraîcher de Houéyiho, à Cotonou au sud-Bénin. Bull la Rech Agron du Bénin 1-12

Agnandji P, Cachon BF, Atindehou M et al (2018) Analyse des pratiques phytosanitaires en maraîchage dans les zones intraurbaines (Cotonou) et péri-urbaines (Sèmè-kpodji) au SudBénin. Rev Africaine D'environnement D'agriculture 1:2-11

Ahouangninou C, Fayomi BE, Martin T (2011) Évaluation des risques sanitaires et environnementaux des pratiques phytosanitaires des 
producteurs maraîchers dans la commune rurale de Tori-Bossito (Sud-Bénin). Cah Agric 20:216-222

Ahouangninou C, Martin T, Assogba-komlan F et al (2013) Using Aedes aegypti larvae to Assess Pesticide Contamination of Soil, Groundwater and Vegetables. Br Biotechnol J 3:143-157

Ahouangninou CCA (2013) Durabilite de la production maraîchère au Sud-Benin : un essai de l'approche écosystemique. Université d'Abomey-Calavi

Akogbeto MC, Noukpo RDH (2005) Utilisation des insecticides agricoles au Bénin. Bull La Société Pathol Exot 98:400-405

Assogba-Komlan F, Anihouvi P, Achigan E et al (2007) Pratiques culturales et teneur en éléments anti nutritionnels (nitrates et pesticides) du Solanum macrocarpum au sud du Bénin. African J Food Agric Nutr Dev 7

Atidegla CS, Euloge K (2010) Pollutions chimique et bactériologique des eaux souterraines des exploitations maraîchères irriguées de la commune de Grand-Popo : cas des nitrates et bactéries fécales. Int J Biol Chem Sci 4:327-337

Atidegla SC (2018) Metallic contamination of vegetables: causes and approach of solutions through environmental education. MOJ Biol Med 3:30-35. https://doi.org/10.15406/mojbm.2018.03. 00072

Atidegla SC, Agbossou EK, Huat J, Kakai RG (2011) Contamination métallique des légumes des périmètres maraîchers urbains et péri urbains : Cas de la commune de Grand - Popo au Bénin. Int J Biol Chem Sci 5:2351-2361

Atidegla SC, Bonou W, Agbossou EK (2018) Relations entre perceptions des producteurs et surfertilisation en maraichage urbain et péri urbain au Bénin. Int J Biol Chem Sci 11:2106. https://doi. org/10.4314/ijbcs.v11i5.14

Azandeme-Hounmalon GY, Affognon HD, Assogba-Komlan F et al (2014) Comportement des maraîchers face a l'invasion de Tetranychus evansi Baker \& Pritchard au Sud du Bénin. In: AFPP - Dixième Conférence Internationale sur les Ravageurs en Agriculture, Montpellier, 22 et 23 Octobre 2014

Azontondé A (1993) Degradation et restauration des terres de barre (sols ferrallitiques faiblement desatures argilo-sableux) au Benin. Cah - ORSTOM, Ser Pedol 28:217-226

Basset-Mens C, Edewa A, Gentil C (2019) An LCA of French beans from Kenya for decision-makers. Indones J LCA Sustain 1:1-11

Bindraban PS, Dimkpa C, Nagarajan L et al (2015) Revisiting fertilisers and fertilisation strategies for improved nutrient uptake by plants. Biol Fertil Soils 51:897-911. https://doi.org/10.1007/ s00374-015-1039-7

Binta BAA, Barbier B (2015) Economic and environmental performances of organic farming system compared to conventional farming system: a case study of the horticulture sector in the Niayes region of Senegal. Procedia Environ Sci 29:17-19. https://doi.org/10.1016/j.proenv.2015.07.132

Birch ANE, Begg GS, Squire GR (2011) How agro-ecological research helps to address food security issues under new IPM and pesticide reduction policies for global crop production systems. J Exp Bot 62:3251-3261. https://doi.org/10.1093/jxb/err064

Bockstaller C, Girardin P (2010) Mode de calcul des indicateurs agrienvironnementaux de la methode Indigo ${ }^{\circledR}$. INRA, Colmar

Boko M (1988) Climats et communautés rurales du Bénin : rythmes climatiques et rythmes de développement. Université de Bourgogne

Boone L, Roldán-Ruiz I, Van linden V et al (2019) Environmental sustainability of conventional and organic farming: accounting for ecosystem services in life cycle assessment. Sci Total Environ 695:133841. https://doi.org/10.1016/j.scitotenv.2019.133841

Bourn D, Prescott J (2002) A comparison of the nutritional value, sensory qualities, and food safety of organically and conventionally produced foods. Crit Rev Food Sci Nutr 42:1-34. https://doi.org/ $10.1080 / 10408690290825439$
Brankatschk G, Finkbeiner M (2015) Modeling crop rotation in agricultural LCAs-challenges and potential solutions. Agric Syst 138:66-76. https://doi.org/10.1016/j.agsy.2015.05.008

Chauvin ND, Mulangu F, Porto G (2012) Food production and consumption trends in Sub-Saharan Africa: prospects for the transformation of the agricultural sector

Clark M, Tilman D (2017) Comparative analysis of environmental impacts of agricultural production systems, agricultural input efficiency, and food choice. Environ Res Lett 12. https://doi.org/ 10.1088/1748-9326/aa6cd5

Clune S, Crossin E, Verghese K (2017) Systematic review of greenhouse gas emissions for different fresh food categories. J Clean Prod 140:766-783. https://doi.org/10.1016/j.jclepro.2016.04.082

CORAF (2010) Cultures maraîchères : des extraits végétaux à la place des insecticides de synthèse. Lett D'information Pour La Rech Le Développement Agric En Afrique L'ouest Du Cent 56:1-16

Cory H, Passarelli S, Szeto J et al (2018) The role of polyphenols in human health and food systems: a mini-review. Front Nutr 5:1-9. https://doi.org/10.3389/fnut.2018.00087

Costa MP, Chadwick D, Saget S et al (2020) Representing crop rotations in life cycle assessment: a review of legume LCA studies. Int J Life Cycle Assess 1942-1956. https://doi.org/10.1007/ s11367-020-01812-x

Coulibaly O, Cherry AJ, Nouhoheflin T et al (2008) Vegetable producer perceptions and willingness to pay for biopesticides. J Veg Sci 12. https://doi.org/10.1300/J484v12n03

Darmon N, Darmon M, Maillot M, Drewnowski A (2005) A nutrient density standard for vegetables and fruits: nutrients per calorie and nutrients per unit cost. J Am Diet Assoc 105:1881-1887. https://doi.org/10.1016/j.jada.2005.09.005

Darmon N, Vieux F, Maillot M et al (2009) Nutrient profiles discriminate between foods according to their contribution to nutritionally adequate diets: a validation study using linear programming and the SAIN, LIM system. Am J Clin Nutr 89:1227-1236. https://doi.org/10.3945/ajcn.2008.26465

de Boer IJM (2003) Environmental impact assessment of conventional and organic milk production. Livest Prod Sci 80:69-77. https:// doi.org/10.1016/S0301-6226(02)00322-6

de Ponti T, Rijk B, Van Ittersum MK (2012) The crop yield gap between organic and conventional agriculture. Agric Syst 108:19. https://doi.org/10.1016/j.agsy.2011.12.004

Del Bo C, Bernardi S, Marino M et al (2019) Systematic review on polyphenol intake and health outcomes: is there sufficient evidence to define a health-promoting polyphenol-rich dietary pattern? Nutrients 11. https://doi.org/10.3390/nu11061355

Diallo F, Masse D, Diarra K, Feder F (2019) Impact of organic fertilisation on lettuce biomass production according to the cultivation duration in tropical soils. Acta Agric Scand Sect B - Soil Plant Sci 0:1-9. https://doi.org/10.1080/09064710.2019.1702715

Dijkman TJ, Basset-Mens C, Antón A, Núñez M (2017) Chapter 29. LCA of Food and Agriculture. In: Life Cycle Assessment: Theory and Practice. pp 723-754

Djouaka R, Zeukeng F, Soglo MF et al (2016) Heavy metal contamination and fecal coliforms in peri-urban market gardening sites in Benin and Cameroon. Int J Agric Environ Res 2:2455-6939

Drewnowski A, Fulgoni V (2008) Nutrient profiling of foods: creating a nutrient-rich food index. Nutr Rev 66:23-39. https://doi.org/ 10.1111/j.1753-4887.2007.00003.x

Drewnowski A, Maillot M, Darmon N (2009) Should nutrient profiles be based on $100 \mathrm{~g}, 100 \mathrm{kcal}$ or serving size? Eur J Clin Nutr 63:898-904. https://doi.org/10.1038/ejcn.2008.53

Duthie GG, Gardner PT, Kyle JAM (2003) Plant polyphenols: are they the new magic bullet? Proc Nutr Soc 62:599-603. https://doi.org/ $10.1079 /$ pns 2003275 
EC-JRC, (2012) Characterisation factors of the ILCD Recommended Life Cycle Impact Assessment methods. Publications Office of the European Union, Luxembourg

EC (2018) Product Environmental Footprint Category Rules Guidance v6.3

El Bilali H (2020) Organic food and farming in West Africa : a systematic review. J Sustain Org Agric Syst 70:94-102. https://doi.org/ 10.3220/LBF1611507579000

Fantke (Ed.) P, Bijster M, Guignard C et al (2017) USEtox ${ }^{\circledR} 2.0$ Documentation (Version 1)

FAO, WHO (2015) General Standard for Contaminants and Toxins in Food and Feed (Codex Stan 193-1995). Codex Aliment 51:3954. https://doi.org/10.1017/CBO9781107415324.004

FAO (2019a) The State of Food and Agriculture 2019. Moving forward on food loss and waste reduction. Rome: Food and Agriculture Organization of the United Nations

FAO (2019b) FAOSTAT Database

Feder F, Bochu V, Findeling A, Doelsch E (2015) Repeated pig manure applications modify nitrate and chloride competition and fluxes in a Nitisol. Sci Total Environ 511:238-248. https://doi.org/10. 1016/j.scitotenv.2014.12.059

Foteinis S, Chatzisymeon E (2016) Life cycle assessment of organic versus conventional agriculture. A case study of lettuce cultivation in Greece. J Clean Prod 112:2462-2471. https://doi.org/10. 1016/j.jclepro.2015.09.075

Foteinis S, Hatzisymeon M, Borthwick AGL, Chatzisymeon E (2021) Environmental impacts of conventional versus organic eggplant cultivation systems: Influence of electricity mix, yield, overfertilization, and transportation Environ - MDPI 8. https://doi. org/10.3390/environments8030023

Gollin D (2014) Smallholder agriculture in Africa: an overview and implications for policy. IIED Work Pap IIED, London 1-20

Green A, Nemecek T, Chaudhary A, Mathys A (2020) Assessing nutritional, health, and environmental sustainability dimensions of agri-food production. Glob Food Sec 26:100406. https://doi.org/ 10.1016/j.gfs.2020.100406

Haas G, Wetterich F, Geier U (2000) Life cycle assessment framework in agriculture on the farm level. Int J Life Cycle Assess 5:345-348. https://doi.org/10.1007/BF02978669

He X, Qiao Y, Liu Y et al (2016) Environmental impact assessment of organic and conventional tomato production in urban greenhouses of Beijing city, China. J Clean Prod 134:251-258. https:// doi.org/10.1016/j.jclepro.2015.12.004

Herrero M, Thornton PK, Power B et al (2017) Farming and the geography of nutrient production for human use: a transdisciplinary analysis. Lancet Planet Heal 1:e33-e42. https://doi.org/10.1016/ S2542-5196(17)30007-4

Hodomihou NR, Feder F, Masse D et al (2016) Diagnostic de contamination des agrosystèmes périurbains de Dakar par les éléments traces métalliques. Biotechnol Agron Soc Environ 20:397-407

ISO (2006) ISO 14044 Environmental management - Life cycle assessment - Requirements and guidelines. The International Standards Organisation

Joubert E, Gelderblom W (2016) Value of antioxidant capacity as relevant assessment tool for " health benefits " of fruit — understated or inflated ? South African J Clin Nutr 29:4-6. https://doi.org/10. 1073/pnas.1422664112

Kalbar PP, Birkved M, Nygaard SE, Hauschild M (2017) Weighting and aggregation in life cycle assessment: do present aggregated single scores provide correct decision support? J Ind Ecol 21:1591-1600. https://doi.org/10.1111/jiec.12520

Kirchmann H, Kätterer T, Bergström L et al (2016) Flaws and criteria for design and evaluation of comparative organic and conventional cropping systems. F Crop Res 186:99-106. https://doi.org/ 10.1016/j.fcr.2015.11.006
Knudsen MT, Meyer-Aurich A, Olesen JE et al (2014) Carbon footprints of crops from organic and conventional arable crop rotations using a life cycle assessment approach. J Clean Prod 64:609-618. https://doi.org/10.1016/j.jclepro.2013.07.009

Koch P, Salou T (2016) AGRIBALYSE ® : Rapport Méthodologique - Version 1.3. ART, INRA, ADEME

Koch W (2019) Dietary polyphenols-important non-nutrients in the prevention of chronic noncommunicable diseases. A Systematic Review Nutrients 11:1-35

Koumolou L, Edorh P, Montcho S, Aklikokou K (2013) Health-risk market garden production linked to heavy metals in irrigation water in Benin. C R Biol 336:278-283. https://doi.org/10.1016/j. crvi.2013.04.002

Kowalczyk Z, Cupiał M (2020) Environmental analysis of the conventional and organic production of carrot in Poland. J Clean Prod 269. https://doi.org/10.1016/j.jclepro.2020.122169

Liao W, Van Der Werf HMG, Salmon-Monviola J (2015) Improved environmental life cycle assessment of crop production at the catchment scale via a process-based nitrogen simulation model. Environ Sci Technol 49:10790-10796. https://doi.org/10.1021/ acs.est. 5 b01347

Lietz G (2020) Overlapping vitamin A intervention programs: should we be concerned with excessive intakes? J Nutr 150:2849-2851. https://doi.org/10.1093/jn/nxaa288

Magkos F, Arvaniti F, Zampelas A (2006) Organic food: buying more safety or just peace of mind? A critical review of the literature. Crit Rev Food Sci Nutr 46:23-56. https://doi.org/10.1080/ 10408690490911846

Maillot M, Darmon N, Darmon M et al (2007) Nutrient-dense food groups have high energy costs: an econometric approach to nutrient profiling. J Nutr 137:1815-1820. https://doi.org/10.1093/jn/ 137.7.1815

Martin KR (2009) Polyphenols as dietary supplements: a double-edged sword Nutr Diet Suppl 1. https://doi.org/10.2147/nds.s6422

Meier MS, Stoessel F, Jungbluth N et al (2015) Environmental impacts of organic and conventional agricultural products - are the differences captured by life cycle assessment? J Environ Manage 149:193-208. https://doi.org/10.1016/j.jenvman.2014.10.006

Mie A, Andersen HR, Gunnarsson S et al (2017) Human health implications of organic food and organic agriculture: a comprehensive review. Environ Heal A Glob Access Sci Source 16:1-22. https:// doi.org/10.1186/s12940-017-0315-4

Nemecek T, Frick C, Dubois D, Gaillard G (2001) Comparing farming systems at crop rotation level by LCA. In: Geerken T, Mattson B, Olsson P, Johansson E (eds) Proceedings of the International Conference on LCA in Foods, Gothenburg. SIK, VITO, Gothenburg, 65-69

Neuweiler R, Krauss J (2017) Fertilisation des cultures maraîchères. Principes Fertil Des Cult Agric En Suisse 8:166-182

OCDE, FAO (2016) L'agriculture en Afrique subsaharienne : Perspectives et enjeux de la décennie à venir. Perspectives agricoles de l'OCDE et de la FAO 2016-2025. Éditions OCDE, Paris, pp 63-104

Payen S, Basset-mens C, Perret S (2015) LCA of local and imported tomato: an energy and water trade-off. J Clean Prod 87:139-148. https://doi.org/10.1016/j.jclepro.2014.10.007

Pérez-Jiménez J, Neveu V, Vos F, Scalbert A (2010) Identification of the 100 richest dietary sources of polyphenols: an application of the Phenol-Explorer database. Eur J Clin Nutr 64:S112-S120. https://doi.org/10.1038/ejen.2010.221

Perrin A (2013) Evaluation environnementale des systèmes agricoles urbains en Afrique de l'Ouest : Implications de la diversité des pratiques et de la variabilité des émissions d'azote dans l'Analyse du Cycle de Vie de la tomate au Bénin. Sciences agricoles. AgroParisTech, 2013. Français 
Perrin A, Basset-Mens C, Gabrielle B (2014) Life cycle assessment of vegetable products: a review focusing on cropping systems diversity and the estimation of field emissions. Int J Life Cycle Assess 19:1247-1263. https://doi.org/10.1007/s11367-014-0724-3

Perrin A, Basset-mens C, Huat J (2015) High environmental risk and low yield of urban tomato gardens in Benin. Agron Sustain Dev 35:305-315. https://doi.org/10.1007/s13593-014-0241-6

Ponisio LC, M'gonigle LK, Mace KC et al (2015) Diversification practices reduce organic to conventional yield gap. Proc R Soc B Biol Sci 282:20141396. https://doi.org/10.1098/rspb.2014.1396

Popa ME, Mitelut AC, Popa EE et al (2019) Organic foods contribution to nutritional quality and value. Trends Food Sci Technol 84:15-18. https://doi.org/10.1016/j.tifs.2018.01.003

Rosenbaum RK, Bachmann TM, Gold LS et al (2008) USEtox-the UNEP-SETAC toxicity model: recommended characterisation factors for human toxicity and freshwater ecotoxicity in life cycle impact assessment. Int J Life Cycle Assess 13:532-546. https:// doi.org/10.1007/s11367-008-0038-4

Rosenberg PE, Gallot J (2002) Référentiel de l'agriculture raisonnée. Arrêté du 30 avril 2002 relatif au référentiel de l'agriculture raisonnée

Salou T, Le Mouël C, van der Werf HMG (2016) Environmental impacts of dairy system intensification: the functional unit matters! J Clean Prod 1-10. https://doi.org/10.1016/j.jclepro.2016. 05.019

Sarris A, Morrison J (2010) Food security in Africa: market and trade policy for staple foods in Eastern and Southern Africa. Food and Agriculture Organization of the United Nations, Rome

Schrama M, de Haan JJ, Kroonen M et al (2018) Crop yield gap and stability in organic and conventional farming systems. Agric Ecosyst Environ 256:123-130. https://doi.org/10.1016/j.agee. 2017.12.023

Srinivasulu R, Victor A-S, Daniel KK et al (2015) Technical efficiency of traditional African vegetable production: a case study of smallholders in Tanzania. J Dev Agric Econ 7:92-99. https:// doi.org/10.5897/jdae2014.0606

Suciu NA, Ferrari F, Trevisan M (2019) Organic and conventional food: comparison and future research. Trends Food Sci Technol 84:49-51. https://doi.org/10.1016/j.tifs.2018.12.008

Thierfelder C, Mombeyarara T, Mango N, Rusinamhodzi L (2013) Integration of conservation agriculture in smallholder farming systems of southern Africa: identification of key entry points. Int
J Agric Sustain 11:317-330. https://doi.org/10.1080/14735903. 2013.764222

Tonfack LB, Bernadac A, Youmbi E et al (2009) Impact of organic and inorganic fertilizers on tomato vigor, yield and fruit composition under tropical andosol soil conditions. Fruits 64:167-177. https:// doi.org/10.1051/fruits/2009012

Truzzi F, Valerii MC, Tibaldi C et al (2020) Are supplements safe? Effects of gallic and ferulic acids on in vitro cell models. Nutrients 12:1-13. https://doi.org/10.3390/nu12061591

Tuomisto HL, Hodge ID, Riordan P, Macdonald DW (2012) Does organic farming reduce environmental impacts? - A metaanalysis of European research. J Environ Manage 112:309-320. https://doi.org/10.1016/j.jenvman.2012.08.018

Vigar V, Myers S, Oliver C et al (2020) A systematic review of organic versus conventional

Vincent A, Grande F, Compaoré E et al (2020) FAO/INFOODS Food Composition Table for Western Africa (2019). User Guide \& Condensed Food Composition Table. Rome: Food and Agriculture Organization of the United Nations

Weidema BP, Stylianou KS (2019) Nutrition in the life cycle assessment of foods-function or impact? Int J Life Cycle Assess 1210-1216. https://doi.org/10.1007/s11367-019-01658-y

WHO (2011) Nitrate and nitrite in drinking-water. World Health Organization, Background document for development of WHO Guidelines for Drinking-water Quality

Williamson G, Holst B (2008) Dietary reference intake (DRI) value for dietary polyphenols: are we heading in the right direction? $\mathrm{Br}$ J Nutr 99:55-58. https://doi.org/10.1017/S0007114508006867

Wooltorton E (2003) Too much of a good thing? Toxic effects of vitamin and mineral supplements. Can Med Assoc J 169:47-48

Worthington V (2001) Nutritional quality of organic versus conventional fruits, vegetables, and grains. J Altern Complement Med 7:161-173. https://doi.org/10.1089/107555301750164244

Yehouenou EAP, Soton A, Azocli D et al (2010) Contamination du sol, de l'eau et des produits maraîchers par des substances toxiques et des métaux lourds sur le site de Houéyiho (Cotonou) en République du Bénin. Int J Biol Chem Sci 4:2160-2168

Publisher's Note Springer Nature remains neutral with regard to jurisdictional claims in published maps and institutional affiliations. 